\title{
Post-crisis regulatory reforms and bank performance: lessons from Asia
}

Article

Accepted Version

Casu, B., Deng, B. and Ferrari, A. (2017) Post-crisis regulatory reforms and bank performance: lessons from Asia. European Journal of Finance, 23 (15). pp. 1544-1571. ISSN 1466-4364 doi: https://doi.org/10.1080/1351847X.2016.1177566 Available at https://centaur.reading.ac.uk/64710/

It is advisable to refer to the publisher's version if you intend to cite from the work. See Guidance on citing.

To link to this article DOI: http://dx.doi.org/10.1080/1351847X.2016.1177566

Publisher: Taylor and Francis

All outputs in CentAUR are protected by Intellectual Property Rights law, including copyright law. Copyright and IPR is retained by the creators or other copyright holders. Terms and conditions for use of this material are defined in the End User Agreement.

\section{www.reading.ac.uk/centaur}

\section{CentAUR}

Central Archive at the University of Reading

Reading's research outputs online 


\title{
Post-crisis regulatory reforms and bank performance:
}

\section{lessons from Asia}

\section{Barbara Casua , Bimei Deng ${ }^{\mathrm{b}}$, Alessandra Ferrari ${ }^{\mathrm{c}}$,}

\begin{abstract}
Based on a large dataset from eight Asian economies, we test the impact of post-crisis regulatory reforms on the performance of depository institutions in countries at different levels of financial development. We allow for technological heterogeneity and estimate a set of country-level stochastic cost frontiers followed by a deterministic bootstrapped meta-frontier to evaluate cost efficiency and cost technology. Our results support the view that liberalization policies have a positive impact on bank performance, while the reverse is true for prudential regulation policies. The removal of activities restrictions, bank privatization and foreign bank entry have a positive and significant impact on technological progress and cost efficiency. In contrast, prudential policies, which aim to protect the banking sector from excessive risk-taking, tend to adversely affect banks cost efficiency but not cost technology.
\end{abstract}

Keywords: regulation and deregulation policies; Asian banking markets; banks efficiency; frontiers.

JEL Classification: G21; G28; D24; C49.

${ }^{a}$ Cass Business School, City University, London, EC1Y8TZ, UK. Email: b.casu@city.ac.uk.

${ }^{b}$ Department of Economics and Trade, Guangdong Polytechnic Normal University, Guangzhou, China. Email: luciedeng@live.cn

'Department of Economics, SPEIR; Whiteknights, University of Reading. Reading RG66AA, UK.

Corresponding author: Alessandra Ferrari, Department of Economics, SPEIR; Whiteknights, University of Reading. Reading RG66AA, UK. Email: a.ferrari@reading.ac.uk. Phone: +44-0118-3786032. Fax: +440118-3786533. 


\section{Introduction}

In this paper we investigate the impact of financial liberalization policies and concomitant prudential regulation initiatives on the performance of Asian banks following the 1997 financial crisis. From a theoretical perspective, the effects of regulation on bank efficiency are not well-defined. The larger part of policy literature on financial regulation has been inspired by the wider debate on the role of government in the economy. The two best-known opposing views in this area are the public interest view and the private interest view. Although both views agree on the assumption of market failure, they disagree on how to minimize it. For the public interest view, governments act in the public interest. In this setting, well-conceived regulation can exert a positive effect on firm behaviour by fostering competition and encouraging effective corporate governance. Therefore, governments regulate to ensure better functioning and thus more efficient banks, ultimately for the benefit of the economy as a whole. The alternative private interest view sees regulation as a product of private interests or lobby groups, who use the coercive power of the state to extract rents at the expense of other groups (Stigler 1971). This view thus suggests that regulation can be used to foster the interest of the few in power and therefore hinder the efficiency of firms, as these are constrained to channel resources to special-interest groups. Given that banking is one of the most highly regulated industries, these distortions could be particularly important and lead to vast inefficiencies.

While the theoretical debate is still unsettled, empirically the private interest view is more consistent with the data. Barth et al. (2008) find that regulatory approaches that support private sector monitoring of banks and strengthen incentives for market monitoring, improve bank performance. 
Nevertheless, there is no evidence of any common set of rules that is universally appropriate for promoting well-functioning banks. Regulatory structures that lead to successful outcomes in some countries may not work in other countries that have different institutional settings. As pointed out by Barth et al. (2013), there is no broad cross-country evidence as to which of the many different regulations and supervisory practices employed around the world work best. As a consequence, the question of how regulation affects bank performance remains unanswered.

Broadly speaking, the changing set of regulation can be classified into rules that foster financial liberalisation and rules that impose restrictions on activities. More specifically, financial liberalization (or deregulation) refers to policies that reduce the restrictions imposed on banks' conduct, including entry, permissible activities or interest rates. Their primary aim is to foster competition and improve the efficiency of financial intermediaries. Prudential rules, on the other hand, aim at improving financial sector stability by imposing capital and liquidity ratios, as well as other forms of control on bank permissible activities. While the aims of financial reforms are clear, to foster a well-functioning financial sector, their long-term economic impact is controversial, as evidenced by the number of financial crises around the world. In addition, different policies can have conflicting objectives and therefore their aggregate impact on the financial sector in the long term may depend upon the timing of the reforms, the structure of the financial sector and the level of financial development of a particular country. The reasons behind the success or failure of particular policies are often complex, and regulators around the world are still struggling with the issue of what is good regulation and which reforms constitute good practice (Ayadi et al., 2016). Despite the relevance of the issue, no general academic consensus exists about the effects of prudential regulation and liberalization on financial sector performance. This 
is all the more important as following the global financial crisis of 2007-09 many countries have embarked on a similar process of reform of their banking sectors.

This paper aims to fill this and related gaps in the literature by exploring how the simultaneous adoption of specific liberalization and prudential regulation policies affected bank performance in eight major Asian economies after the 1997 crisis. We collect bank regulation information from four recent world-wide surveys conducted by Barth, Caprio and Levine (2001, 2003, 2007 and 2012) and made available by the World Bank. We examine the impact on bank efficiency of capital regulation, activities restrictions, supervisory powers, credit market deregulation and market discipline. From a theoretical perspective, the predictions are not clear. For example, more stringent capital regulation should promote better bank performance as higher capital aligns the interests of bank shareholders, depositors and creditors and should result in increased lending standards and lower banks' risk taking incentives. On the other hand, costly capital can increase entry barriers, thereby decreasing competition and allowing banks to extract monopoly rents.

Similar opposing views are put forward with regards to activities restrictions. On the one hand restrictions prevent banks from diversifying into more profitable sources of income and therefore should be negatively related to bank performance. On the other hand, by increasing the complexity of banks activities diversification can increase moral hazard and provide opportunities for increased risk taking and ultimately impact negatively on bank performance.

Powerful supervisors should monitor and discipline banks effectively, thereby fostering good corporate governance and good performance. On the other hand, powerful supervisors may abuse their power and constrain the allocation of credit for political reasons. Finally, greater market discipline should encourage well performing banks. 
However, market discipline is achieved through mandatory information disclosure, which can be costly. These different mechanisms are constantly at play and therefore the impact of various regulatory changes on bank efficiency remains an empirical question. More details on the relevant theoretical and empirical literature are offered in Section 3.

The period that followed the 1997 Asian financial crisis provides us with a unique opportunity to address these issues, given the unique and dynamic regional characteristics of the Asian banking markets. The region comprises countries at different stages of economic and financial development. In the aftermath of the crisis, the process and pace of their regulatory reforms varied substantially. In most countries, the renewed emphasis on financial reform translated into the adoption of tighter prudential rules and restructuring programmes which went hand in hand with the acceleration of liberalization policies aimed at restructuring the financial services sector and promote economic growth. This process resulted in substantial changes in market structure, deriving both from greater foreign presence and from increased privatization across the region. Such diversification provides us with an excellent laboratory to understand the impact of regulatory reforms on banks' performance.

To investigate this issue, we build a large panel dataset encompassing depository institutions from China, Hong Kong, India, Indonesia, Japan, Malaysia, the Philippines and Thailand over the period 2001-2010. We control for different ownership structures, concentration and risk, as well as for the separate impact on efficiency of different policy changes. The length of our time series allows us to analyse the effects of both financial liberalization and the reintroduction of prudential policies on efficiency and cost technology. This longer time span also allows for a fuller development of the policy effects, enhancing the reliability of the results. In this, we provide a novel 
contribution, as most of the existing literature on the impact of the Asian crisis focuses on its immediate aftermath and empirical investigations often stop in the early $2000 \mathrm{~s}$. Unlike most of the literature we test for and find technological heterogeneity across countries, which prevents the use of a pooled data set. We therefore estimate a set of stochastic cost frontiers at the country level first, followed by the estimation of a deterministic, bootstrapped cross-country meta-frontier, that allows us make reliable cross country comparisons and explore in detail which countries and bank types led the technological developments of the period.

Our main results show that liberalization policies such as the removal of activities restrictions, privatization and opening to foreign banks have a positive and significant impact on technological progress and cost efficiency. In contrast, prudential reregulation policies tend to adversely affect banks cost efficiency although they do not significantly impact on cost technology.

Policies that aim to strengthen prudential regulation should take into account the potential negative effects on bank efficiency, with a view to balance the need to foster stability without hindering financial intermediation. Our results are consistent with Barth et al (2013), who find that tighter restrictions on bank activities are negatively associated with bank efficiency while greater capital regulation, greater official supervisory power and enhanced market-based monitoring are positively associated with bank efficiency.

The use of a meta-frontier model allows us to compare banks cross-country and to identify which banks from which countries utilize the best available technology. We find that Chinese and Japanese banks are the best performers in the region, with the highest median efficiency scores and the highest number of technology leaders (i.e. banks on the meta-frontier). Japanese banks enjoy the benefits of the "Financial Big Bang" of the 
late 90 s, whose effects last into the early 2000s. Chinese banks overtake their Japanese peers from 2006 onwards, consistently with the boom period in the Chinese economy corresponding to the full implementation of its ambitious financial reforms. While Chinese banks were not affected by the 1997 Asian financial crisis, banks in Hong Kong, Malaysia and the Philippines suffered considerably. In Malaysia in particular, the crisis resulted in the tightening of prudential policies and restrictions on permissible activities, which possibly contributed to their poor performance. Finally, our results also show that private and foreign banks play a key role in promoting technological progress across the region, therefore providing supporting evidence to the benefits of foreign bank presence in terms of technological spill-overs. The influence of foreign banks can be seen by looking at their proportion among technology leaders. While this is very high in Hong Kong, given the structure of its banking system, it is also very important in China where they have a very small market share. It appears that the opening of the banking sector to foreign banks has enabled Chinese banks to benefit from technological spill-overs.

The rest of the paper is structured as follows. Section 2 gives an overview of the Asian banking systems and the changes following the financial crisis. A review of the literature on the efficiency effects of banking regulation and liberalization is provided in Section 3, while Section 4 describes the data and the methodology. Section 5 presents the empirical results, and concluding remarks are presented in Section 6.

\section{An overview of Asian banking}

Bank intermediation plays an important role in Asian financial systems, matched by relatively under-developed capital markets. The pace and timing of financial reforms varied widely across the region; some countries started as early as the 1970s and early Page $\mid 7$ 
1980s (Japan, Malaysia, Indonesia and the Philippines) while others embarked in major reform programs only in the 1990s (India, Hong Kong, Thailand) or later (China). Liberalization policies usually commenced with interest rates deregulation and in some instances moved to the opening of capital accounts to international investors, and to differing levels of privatization and foreign bank entry (Klapper et al., 2014). The fast pace of some of these liberalization processes, coupled with the free capital flows, pegged exchange rates, and weak management and legal systems, led to the financial crisis of 1997, which started in Thailand and quickly spread to varying degrees to neighbouring countries. During the crisis a number of banks failed whilst others were nationalized, restructured and later re-privatized. The restructuring programs (in the form of compulsory M\&As) worked as an exit strategy for weak banks in Indonesia, Malaysia, the Philippines, Thailand and Japan until about 2001, becoming more market driven thereafter. In countries less affected by the crisis, such as China, Hong Kong and India, structural changes in the domestic banking sector were primarily the result of the acceleration of bank liberalization and of reforms in corporate governance.

The interplay of the various reforms led to significant changes in market structure, the most relevant of which are reported below. As we can see in Figure 1, ownership structure becomes increasingly diversified. The efficiency-driven corporate governance reforms reduce the state ownership of banks especially in the countries where it was predominant, increasing the role of foreign and private institutions. The resulting patterns are however very different across the region.

\section{Insert Figure 1 here}

The change in market structure shows up also in the concentration of assets, as measured by the CR5 (the aggregate share of the top 5 banks) reported in Figure 2: while concentration increases in markets traditionally dominated by families or the 
private sector (such as Hong Kong, Japan, Malaysia and the Philippines), a gradual process of decentralization takes place in those formerly dominated by state-ownership (China, Indonesia and India), as a result of privatization.

\section{Insert Figure 2 here}

Changes in concentration do not necessarily imply changes in competitiveness, so more specific information is reported in Table 1 for the period of analysis. The table also includes the average value for the region as well as values for the European Monetary Union (EMU) and the US for comparative purposes.

\section{Insert Table 1 here}

The general pattern in net interest margins (NIM) is increasing, suggesting a possible reduction in the competitiveness of banking sectors - the opposite trend as observed in their Western comparators. This could be due, among other things, to the shift of regulatory focus from deregulation to bank re-regulation and the adoption of international banking practices (the Basel Accords) to strengthen the banking system. The rest of Table 1 seems to suggest that these efforts produced positive results. Capital adequacy ratios $(C A R)$ increase and by 2010 they exceed $9 \%$ of total assets in most economies. This extra prudence is justified by the relatively high levels (by international standards) of non-performing loans (NPL) which however steadily decline from a regional average of $18 \%$ to less than $3 \%$. In addition, increased return on assets $(R O A)$ and lower cost to income ratios (CIR) could suggest an improvement in operational efficiency, as opposed to the worsening profitability in the EMU and US where performance is clearly affected by the recent financial crisis.

The above are very general statistics on how the interplay of regulation and deregulation might have affected Asian banking markets. Although they appear to have been relatively resilient to the global financial crisis, uncertainties remain about their long Page $\mid 9$ 
term development. We review the main contributions of the literature in the next section, before embarking on our empirical work.

\section{Regulatory reform and efficiency: a brief literature review}

Financial deregulation (or liberalization) refers to policies that reduce the restrictions imposed on banks' entry, permissible activities or interest rates. Their primary aim is to foster competition and improve the efficiency of financial intermediaries, but their ultimate effects are controversial.

Earlier studies focus on the US and produce mixed results (see for example Bauer et al., 1993; Jayaratne and Strahan, 1996; and Berger and Mester, 2003). Studies focusing on Western Europe tend to find a positive relationship between deregulation and bank efficiency (Hasan and Marton, 2003), as do some more recent studies investigating Central and Eastern Europe (Koutsomanoli et al., 2009; Davutyan and Yildirim, 2015). Focusing on Asian markets, a positive relationship between deregulation and productivity growth is found by Gilbert and Wilson (1998) for Korean banks in the late 80s and early 90s; and by Leightner and Lovell (1998) for the Thai banking market between 1990 and 1994. Chen et al. (2005) examine the impact of China's financial deregulation in the mid-1990s and find an improvement in cost efficiency. Fu and Heffernan (2009) highlight the modest improvements in performance in the early stages of reform in China, mainly enjoyed by joint-stock banks, and conclude in favour of further market openness and liberalization. Looking at India, while Kumbhakar and Sarkar (2003) find no growth in banks' total factor productivity (TFP) following financial liberalization in the early 1990s, Zhao et al. (2010) and Casu et al. (2013) extend the period of observation to 1992-2009 and find instead a sustained growth in

\footnotetext{
${ }^{1}$ Davutyan and Yildirim find that the improvements in the competitiveness and profit efficiency of Turkish banks do however vary with ownership type. Foreign and private institutions lead the changes while State banks lag behind due to political interference.
}

Page $\mid 10$ 
TFP, mainly led by technological progress and by the role played by foreign banks. An interesting post-crisis, cross-country analysis is offered by Chan et al (2014), who use DEA and Tobit models to evaluate the impact of off-balance sheet exposure and other risk measures on the cost and profit efficiency of 7 East Asian countries. While their focus, methodology and sample are different from ours some of their findings are similar especially in terms of relative cost efficiency rankings.

A great deal of the literature focuses specifically on the effects of foreign banks entry, once again with opposite views and findings. Foreign banks from more developed banking systems are expected to have superior management skills, screening and production technologies, efficiency and profitability. This can benefit host countries via technological improvements, increased competition and improved stability (Althammer and Haselman, 2011; Luo et al, 2015). On the other hand foreign banks might suffer from cost and informational diseconomies due to operating from a distance and from their different modes of entry (Naaborg and Lensink, 2008; Claeys and Heinz, 2014); or they might cherry pick the best customers thus damaging the profitability of local institutions ${ }^{2}$.

The (enormous) empirical evidence again is mixed but generally positive. Focusing on Asian markets, the cross country studies of Laeven (2005) and Williams and Nguyen (2005) find that foreign banks have stronger profit efficiency, which is transferred to local banks with a lag. Similar conclusions are reached for South Korean markets by Jeon and Miller (2005) and Jeon et al. (2006); by Casu et al. (2013) for India; by Detragiache and Gupta (2006) for Malaysia; and by Jiang at al. (2009), Lin and Zhang (2009) and He and Fan (2004) for China, who also point out the benefits that foreign banks carry in terms of new and better services. Similar conclusions are reached by Luo

\footnotetext{
${ }^{2}$ A good review of the literature on foreign bank entry is provided Clarke et al., (2003).
} 
et al. (2015) who find strong evidence of the beneficial knowledge transfer effects from foreign to domestic banks in China. They find that proximity to foreign branches increased the profitability and efficiency of domestic banks especially in the period of greater liberalization.

Overall, the empirical evidence on the effect of deregulatory policies on bank productivity growth and efficiency is mixed. This outcome may relate to the fact that deregulation comprises of many different policy initiatives which can impact on bank performance in different ways. However the existing literature tends to treat deregulation as one aggregate policy, rather than considering its multi-faceted nature. A further difficulty arises from the fact that often governments implement deregulatory policies along with re-regulatory ones, which complicates the analysis of their effects.

Re-regulation (or prudential re-regulation) refers to a mixture of supervisory and restrictive policies that aim to protect the banking sector from excessive risk-taking. The instruments of prudential re-regulation have evolved over time in a number of ways. Firstly, given the increasing complexity of the banking business, the objective of official supervision shifted from monitoring banks' activities to fostering banks' internal management. Secondly, capital norms tightened over time. Thirdly, private monitoring that relies on market mechanisms to discipline banks' activities became a key tool of the supervisory system. These elements constitute the three pillars of the Basel accords.

From a theoretical point of view these instruments may have opposite effects on bank performance, and this uncertainty is reflected in the inconsistency of empirical evidence. For example higher capital requirements may lower banks' cost of borrowing as banks are perceived as safer and less likely to fail. On the other hand they might burden banks with unnecessary costs. In particular, if banks are forced to raise equity capital at a price higher than the interest rate on deposits, an increase in capital 
requirements may discourage bank lending (Thakor, 1996). Official supervision may reduce market failures by monitoring banks and improving the quality of bank lending (Beck et al., 2006). Powerful supervisors, however, may abuse their powers to benefit their associates and extract bribes (Shleifer and Vishny, 1998) with detrimental effects on bank intermediation. Finally, the success of market discipline depends crucially on the accuracy of investors' information on the financial conditions of a bank, and on their ability to influence, via their behaviour, the behaviour of other banks (Bliss and Flannery, 2002). Given the complexity and opacity of the banking sector, the effective implementation of private monitoring is difficult even in developed economies. For this reason, reliance on private monitoring may lead to the exploitation of depositors and poor bank performance.

From an empirical perspective, one of the earliest studies analysing the link between regulation and efficiency is that of Demirgüç-Kunt et al. (2004) who find that tightening regulation increases the cost of intermediation, but that the role of regulatory variables becomes insignificant when controlling for economic freedom or property rights protection. These results support the view that different bank regulations cannot be viewed independently. Similarly Barth et al. (2004) find that tightening activity restrictions lowers banks' efficiency. In addition they show that policies that enforce accurate information disclosure and private monitoring work best to enhance bank efficiency, whereas they find no evidence that capital requirements and official supervisory power improve bank performance. A voluminous literature supports the view that private monitoring contributes to the improvement of bank efficiency (Pasiouras et al., 2009; Haw et al., 2010; Delis et al., 2011), while only limited evidence exists that official supervisory oversight and capital requirements help improve financial intermediation (Pasiouras et al., 2009). In particular, Chortareas et al. (2012) find that 
all forms of regulatory policy hamper the efficient operation of banks. These results raise a cautionary flag as to the effects of regulation on bank performance.

Very few studies look at the Asian markets. Thangavelu and Findlay (2013) examine the impact of banks off-balance sheet activities, foreign penetration, regulation and supervision on the DEA-efficiency scores of six South-East Asian banking markets between 1994 and 2008. They find that official supervision helps improve banks' efficiency but that private monitoring actually decreases it. Zhao et al. (2010) and Casu et al. (2013) identify a sustained productivity growth in India following the prudential reregulation period but do not separately identify the re-regulatory instruments. Banker et al. (2010) investigate the post-1997 regulatory changes in South Korea and find that policies aimed at strengthening banks' capital structure and risk management do not have a uniform impact on bank productivity, but rather favour strategically privileged banks. Overall the little existing evidence from the Asian banking markets seems to suggest that supervisory oversight works better than private monitoring, possibly because it is more difficult for emerging economies to move towards a disclosure strategy, given that information asymmetry problems are more acute.

We highlighted in the introduction how we think our study contributes to the existing literature. Our data, methodology and empirical results are therefore explored next.

\section{Methodology and data.}

The general aim of this paper is to analyse how regulatory reforms and various bank characteristics have affected bank cost efficiency on a panel dataset of eight Asian economies and to identify the countries and types of bank that led the technological changes. First, we test for technological heterogeneity using likelihood-ratio (LR) tests. We strongly reject the null hypothesis and conclude that banks from different countries 
operate under different technologies. As a consequence we estimate a set of countrylevel stochastic frontiers to analyse the determinants of cost efficiency, followed by the estimation of a meta-frontier in order to make cross-country comparisons.

In the remainder of this section we first present the stochastic frontier model; then we describe the dataset and variables in more detail and provide some descriptive statistics; finally we discuss the meta-frontier model.

\subsection{The stochastic frontier model}

The stochastic frontier approach is a long established model for measuring firms' efficiency $^{3}$. The essence of the model consists of measuring firms' efficiency as the distance from a best performance frontier which is not explained by statistical noise. In general terms, and within a panel setting, a stochastic cost frontier is specified as:

$T C_{i t}=T C(X ; \beta)+\varepsilon_{i t}$

where $\varepsilon_{i t}=v_{i t}+U_{i t .}$ In (1) the observed total cost $T C$ of bank $i$ at time $t$, depends on a set of independent variables $\mathrm{X}$ and on a vector of parameters $\beta$ to estimate. The peculiarity of the model lies in its composed error term $\varepsilon_{i t}$ given by the sum of a symmetric, normally distributed random noise component $v_{i i}^{\sim} N\left(0, \sigma^{2}\right)$ and a non-negative component $u_{i t}$ representing firm-level inefficiency. Following Battese and Coelli (1995) inefficiency can be expressed as a function of some variables $Z$ by modelling it as a truncated normal distribution with variable mean and constant variance, that is $u_{i t} \sim N\left(Z_{i i} \delta, \sigma_{u}^{2}\right)$, as in:

$u_{i t}=Z_{i t} \delta+e_{i t}$

\footnotetext{
${ }^{3}$ Details about the estimation of stochastic frontier models, including the process for model selection, can be found for example in Kumbhakar and Lovell (2000). 
The error $e_{i t}$ in (2) is defined by truncating a 0 -mean normal distribution at point $-Z_{i} \delta$, to guarantee that $u_{i t}>0$. Equations (1) and (2) are estimated simultaneously by Maximum Likelihood, thus avoiding the problems related to two-stage estimation procedures.

To allow for flexibility in the estimation of (1) and following an established literature we choose a translog functional form. Our full model specification is written as:

$$
\begin{aligned}
& \ln T C_{i t}=\alpha_{0}+\sum_{n=1}^{3} \beta_{n} \ln w_{n i t}+\sum_{k=1}^{3} \gamma_{k} \ln q_{k i t}+\sum_{n=1}^{3} \sum_{m=1}^{3} \beta_{n m} \ln w_{n i t} \ln w_{m i t}+ \\
& +\sum_{k=1}^{3} \sum_{j=1}^{3} \gamma_{k j} \ln q_{k i t} \ln q_{j i t}+\sum_{n=1}^{3} \sum_{k=1}^{3} \zeta_{n k} \ln w_{n i t} \ln q_{k i t}+\sum_{r=1}^{3} \xi_{r} R K_{r i t}+ \\
& +\sum_{n=1}^{2} \vartheta_{n} R G_{n i t}+\eta_{1} T+\eta_{2} T^{2}+v G D P_{t}+u_{i t}+v_{i t} \\
& u_{i t}=\delta_{0}+\delta_{1} C M D_{t}+\delta_{2} A C T R_{t}+\delta_{3} C A P S_{t}+\delta_{4} S U P P_{t}+\delta_{5} M A R D_{t}+ \\
& +\delta_{6} S T A T E_{i t}+\delta_{7} \text { FOR }_{i t}+\delta_{8} \operatorname{COOP}_{i t}+\delta_{9} H H I_{t}+\delta_{10} T+\delta_{11} T^{2}+e_{i t}
\end{aligned}
$$

In Equation (3) the dependent variable is total cost $T C$, which is defined as the sum of total interest and operating expenses. In the specification of the inputs and outputs, we follow the intermediation approach and specify input prices ( $w)$ as price of labour $(P L)$, price of physical capital $(P C)$, and price of funds $(P F)$, respectively'; outputs $(q)$ are defined as net loans $(L N)$, other earning assets $(O E A)$, and net fees and commissions $(\mathrm{NFC})$. Net loans are used instead of gross loans to control for the differences in output quality. Net fees and commissions are included as an output because fee-based activities constitute an increasing source of income for banks (Chan et al., 2014). Various studies have highlighted the importance of incorporating risk factors on bank cost technology, as a bank's strategic decisions regarding asset quality and capital composition affect the risk premium of its outputs and input prices (Mester, 1996, Hughes and Mester, 2013). We control for three risk factors $(R K)$ in our model: capital ratio $(C R)$, volatility of

\footnotetext{
${ }^{4}$ For reasons of space we provide the details on variables calculation in the appendix, Table A1.
} 
returns on assets (VOroa) and loan loss provisions (LLP). CR reflects the risk preferences of banks. A risk-averse bank might hold a capital level above the minimum regulatory requirement. Since capital is often more expensive than deposits this might translate into higher costs. On the other hand, better capitalisation and lower leverage can signal the bank as a less risky institution and this could reduce its cost of borrowing on the interbank market. VOroa reflects banks' overall risk. Riskier banks may be more profitable but might incur higher costs to manage the risk. Finally, LLP measures banks' credit risk: a higher level of loan loss provisions signals a higher probability of loans default and therefore lower average asset quality. On the one hand, poorer asset quality should increase banks' borrowing costs; on the other hand, it could be the result of a lower ex ante investment in screening and monitoring activities which would show up as short-run cost savings.

In line with the aims of the analysis, individual policy measures are entered in Equation (4) as determinants of inefficiency, and are described more in detail below and in Table A1. Their aggregate effect $t^{5}$ on the cost frontier is captured by two regulatory indicators $(R G$,$) which are computed as averages of the individual policy indices: a deregulation$ variable (Dereg) and a re-regulation variable (Rereg), measuring respectively the extent to which the banking market of a country is liberalised and the strength of prudential regulations. Finally a quadratic time trend ( $T$ and $T^{\mathfrak{Z}}$ ) captures technological progress over time, and annual GDP growth (GDP) controls for other differences in the general macroeconomic environment.

\footnotetext{
${ }^{5}$ Unfortunately we could not include these effects separately also in the deterministic part of the frontier. In two countries collinearity issues would have made the set of variables different and this would violate the requirement of consistency in variables and functional form between the stochastic frontiers and the meta-frontier (Battese and Rao, 2002).
}

Page $\mid 17$ 
Coming to the determinants of inefficiency of Equation (4), ACTR and CMD are indices of banking deregulation. The former measures the removal of activity restrictions. The latter the extent of credit market deregulation, such as the removal of interest rate controls, the intensity of competition from foreign banks etc. (see Appendix A for more details). In both cases, the higher is the index value the more liberalised is the banking system. Their average constitutes the aggregate deregulation measure (Dereg) that enters the deterministic part of the stochastic frontier. CAPS, SUPP and MARD are measures of prudential re-regulation corresponding to the 3 pillars of the Basel agreements: they are indices respectively of the strength of capital stringency policy, of supervision power and of market discipline. Greater values indicate more stringent capital requirements, stronger supervisory oversight and a higher degree of information disclosure. Their average constitutes the aggregate measure of reregulation (Rereg) that enters the deterministic part of the stochastic frontier. All regulatory indices are scaled by the maximum value in each group to ensure that they are bound between 0 and 1, easing comparisons and aggregation. We also include the dummies STATE, FOR, and COOP to capture State, foreign and cooperative ownership respectively, thus leaving private domestic ownership as the base category. Finally we control for the degree of market concentration with the HerfindhalHirshman index (HHI). A highly concentrated banking market could signal uncompetitive conditions and hence have detrimental implications for efficiency.

\subsection{Data}

Our sample consists of a panel of bank-level and country-level data from eight Asian economies (China, Hong Kong, India, Indonesia, Japan, Malaysia, the Philippines and Thailand) over the period 2001-2010. The sample includes all types of depository institutions (commercial banks, saving banks and cooperatives - except for cooperative 
banks from Japan'), resulting in a total of 3,576 observations, after allowing for outliers and missing data. Table 2 provides some summary statistics for each of the eight countries across the period of study. Financial information is obtained from Bankscope.

\section{Insert Table 2 here}

As showed by the volume of total assets, costs and output levels reported in Table 2, banks in Japan, China and Hong Kong are substantially larger than in other countries and also enjoy lower input prices. In all cases loans are the most important output, whereas fees and commissions have a much smaller weight. The countries that were most affected by the Asian crisis tend to have higher capital ratios, larger return volatilities and higher loan loss provisions. As we observed before, State ownership still plays a predominant role in China, India and Indonesia, and the presence of foreign banks is generally very limited, especially if compared to other emerging economies. Table 3 and Figure 3 show the patterns of the individual and aggregate indices of deregulation and re-regulation, respectively. All regulatory variables are not continuous but collected at four separate points in time. They are obtained from the World Bank survey database (Barth et al., 2001, 2003, 2007, 2012) and the Economic Freedom Index of the Heritage Foundation.

\section{Insert Table 3 here}

\section{Insert Figure 3 here}

Hong Kong is by far the most liberalised country and together with Japan is the only case where the degree of deregulation remains consistently higher than that of reregulation. In all other cases the aggregate index of re-regulatory policies catches up and

\footnotetext{
${ }^{6}$ There are more than 400 cooperative banks in Japan and they are small, local, "not-for-profit" organizations. Kano and Tsutsui (2003) find that loan markets for cooperative banks in Japan are segmented by prefecture, implying that they do not compete on the same platform as the regional and national players. We therefore decided to exclude them from our sample. For a specific analysis of the efficiency of Japanese cooperative banks see for example Glass et al. (2013).
}

Page $\mid 19$ 
even overtakes that of deregulation. China's more cautious liberalization approach is reflected by its lower levels of deregulation (they are the lowest in the sample) and their slower increasing pattern compared to the much stronger increase in re-regulation. Despite having among the lowest capital requirements China places a relatively greater effort on information disclosure to foster market discipline and by the end of the sample period it has the second highest aggregate level of re-regulation. Capital stringency requirements increase steadily throughout the sample but particularly so in Indonesia and the Philippines. Both countries, along with Thailand, were among the first to introduce liberalization policies before the Asian crisis as well as among the worst affected by it. All countries show increasing levels of re-regulation, while the patterns of deregulation vary. This heterogeneity is very useful for our intended research purposes.

\subsection{The meta-frontier model}

Many researchers have observed that the assumption of a common frontier in a crosscountry scenario is quite unwarranted given the differences in banking environments and in the level and quality of services associated with bank intermediation (Dietsch and Lozano-Vivas, 2000; Chaffai et al., 2001). If the banking technology across, say, $g$ countries is not homogeneous then the estimation of a pooled frontier will produce biased results. As a solution, Battese and Rao (2002) and Battese et al. (2004) propose a meta-frontier model. The meta-frontier is conceived as a theoretical super-technology (the meta-technology) that all the $g$ individual technologies belong to and can theoretically access. In other words, the meta-frontier models the possibility of technological spill-overs between the different $g$ groups (countries) even if such spillovers are not perfect and therefore we observe technological heterogeneity.

Page $\mid 20$ 
The meta-frontier can be estimated by linear programming as a deterministic, parametric function that envelops the $g$ country-specific frontiers. In particular, if each country-specific frontier is given by

$$
C_{i t}^{g}=\exp \left(X_{i t} \beta^{g}\right) \exp \left(v_{i t}^{g}+u_{i t}^{g}\right)
$$

with its own set of parameters $\beta^{s}$, the meta-frontier is defined as:

$$
C_{i t}^{*}=f\left(X_{i t} \beta^{*}\right)=\exp \left(X_{i t} \beta^{*}\right)
$$

Equation (6) has the same functional form as Equation (5) and its own set of parameters $\beta^{*}$ estimated subject to the constraint $X_{i} \beta^{*} \leq X_{i} \beta^{\kappa}$, to guarantee that the meta-cost technology will never have costs larger than any of the country-specific cost technologies.

The distance of each firm from the meta-frontier defines its meta-efficiency; this is given by the product of the country-specific inefficiency and the Technological Gap Ratio (TGR), i.e.:

$u_{i t}^{*}=u_{i t}^{g} * T G R_{i t}$

The TGR therefore measures the distance between the meta-frontier and the countryspecific frontier and it is $\leq 1$. The closer to 1 is a firm's TGR value, the closer that firm is to using the optimal meta-technology. TGRs can therefore offer valuable insight about the technological differences between countries or types of bank, and about changes in technological progress and its spill-over. In particular, the identification and analysis of the characteristics of the technical leaders in the region (i.e. the banks on the meta-frontier, with TGR values close to or equal to 1) is especially revealing in this respect. 
Since the meta-frontier is a deterministic method no statistical distribution is modelled for the estimators, which rules out the possibility of statistical testing. To overcome this limitation we use bootstrapping techniques and construct confidence intervals and test statistics on the basis of 1000 bootstrap repetitions.

\section{Empirical results}

In this section we first discuss the results of the estimation of the country-specific frontiers and the determinants of banks cost efficiency. We then look at the results of the estimation of the meta-frontier and discuss in particular the dynamics of banks TGR scores.

\subsection{Country-specific stochastic frontiers.}

Table 4 reports the results from the estimation of the country frontiers. The top part of the table shows the main results of the cost frontier itself, the bottom part the marginal effects of the determinants of inefficiency ${ }^{7}$.

\section{Insert Table 4 here}

All cost frontiers meet their theoretical requirements, with positive and significant elasticities with respect to output levels and input prices. The third output of net fees and commissions shows limited significance, probably due to its low levels in the production technology of Asian banks. A simpler Cobb-Douglas technology is strongly rejected in all cases ${ }^{8}$ and constant or very mildly decreasing returns to scale characterise production. This means that scale economies have generally been exhausted, the structural reorganization following the crisis has been successful (Klapper et al., 2014) and further increases in bank size would not be recommended. The effect of time in terms of technological progress varies considerably. Indonesia and the Philippines have

\footnotetext{
${ }^{7}$ We report the marginal effects directly, rather than the estimated coefficients, as they are more directly interpretable.

${ }^{8}$ This is Wald test 1 in the table.

Page $\mid 22$
} 
a significant concave pattern in cost, with initial technological regress followed by an improvement later into the data series. Thailand and Japan have the very opposite pattern, while other countries show mixed, non-significant changes. The risk measures have consistent and significant impacts on total costs. Increases in capital ratios in most cases have a cost reduction effect. This lends support to the view that if banks are perceived as safer they can benefit from a lower cost of borrowing, counterbalancing the effect of the higher price of capital. The result is in line with Isik and Hassan (2002) and Havrylchyk (2006). The exceptions are Malaysia, the Philippines and Thailand who also have the largest capital ratios of the sample (see Table 2). This suggests that the effect on costs of capital ratios might not be linear but depend on the variable's level. The negative coefficient of VOroa suggests that the pursuit of higher risk projects is not matched by the use of more sophisticated and thus more expensive activities to manage them. Again a possibly non-linear pattern is suggested by the significant positive coefficient for Thailand who also has the highest levels of VOroa in the sample. This would explain the contradictory conclusions reached by previous literature as of the effect of different risk variables. Finally loan loss provisions have a cost increasing effect, as they indicate a lowering of the quality of the loan portfolio and an increase in the likelihood of default. Deregulation and re-regulation in aggregate have a limited effect on the cost technology as such, whereas they have a significant effect, as we will see, on efficiency ${ }^{9}$. The only country where deregulation has a significant cost reduction effect is China, which is also the only case where regulatory policies do not affect efficiency at all. China of course is the only transition economy in the sample; it is not surprising

\footnotetext{
${ }^{9}$ The lack of significance could also be due to the fact that these are aggregate measures. This would be the case if different regulatory policies were to affect technology, and not just efficiency, in a different way; or if low variability were to result from the components moving in opposite directions. We thank an anonymous referee for pointing this out. Unfortunately, as mentioned in footnote 6, econometric requirements prevented us from entering these variables in a disaggregated form in this part of the frontier.
}

Page $\mid 23$ 
then that the changes induced by deregulation would be much more far fetching than in other countries, and affect the whole technology of production, rather than just the efficiency with which some banks adopt it. Conversely re-regulation is generally expected to increase costs but this is significant only in Japan. Deregulation also has a positive albeit economically very small effect in Japan and a very sizeable one instead in the Philippines ${ }^{10}$. Finally, the lack of significance of GDP growth is probably a result of the exhaustiveness of the model. GDP growth in fact is included as a residual category of the general macroeconomic environment, and most of the effects are already satisfactorily captured by the model specification, in particular by the time trend and the policy variables ${ }^{11}$.

Turning to inefficiency, this is highly significant in all countries, it is on average quite high and changes moderately over time (as shown later in Figure 4). The regulatory variables are jointly significant in determining it $^{12}$ except in China: as we said above, policy changes in this country seem to directly affect the technology of production, rather than the efficiency with which it is applied by individual banks. Overall deregulation policies tend to improve efficiency whereas re-regulation ones tend to reduce it. Individual significance levels vary, probably also a reflection of the correlation between measures. If we focus on the sign of the various coefficients, the removal of activities restrictions (ACTR) generally improves efficiency, except in China and Thailand. The result for Thailand can be explained by the historical pattern of the changes in the variable. Being the first and possibly the worst hit by the Asian crisis, unlike in most of its regional peers, in Thailand the level of activity restrictions increases over time. The fact that lower restrictions are linked to higher inefficiency has probably

\footnotetext{
${ }^{10}$ The size of the coefficient for the Philippines has to be taken with caution as the variable's high levels and low variability make it highly correlated with the intercept.

${ }^{11}$ This is true also if we use GDP per capita instead of GDP growth.

12 This is Wald test 2 in the table.
}

Page $\mid 24$ 
a lot to do with the proximity to the crisis itself, as confirmed also by the convex time trend (indicating improvements in efficiency over time). In general the difference in sign, size and significance could be due to the level of development of the banking sector and the experience of its managers at dealing with activities other than traditional intermediation; but also to the level of implementation of the policy itself (see Table 3). Credit market deregulation (CMD) instead has an almost invariably positive and significant effect on efficiency. This result is to be expected as the variable measures things such as competition from foreign banks and the removal of controls on interest rates, all of which are expected to be beneficial to the efficiency of banks. Only in Hong Kong, who has the highest levels of deregulation of the sample, does this effect become negative, although its size is very small. Similarly to the effect of capital ratios on the costs of production, higher capital stringency requirements (CAPS) generally reduce efficiency, with the notable exception of Japan whose levels are however among the lowest in the sample. The negative effect is particularly strong in the Philippines, which adopted the most stringent rules of all. The results lend some support to Barth et al. (2006), who found no evidence that stringent capital regulations enhance the efficiency of bank intermediation. Increases in supervisory powers (SUPP) also mostly affect efficiency negatively, with the exception of Hong Kong and Malaysia. For the former the effect is very small to be economically meaningful; for the latter it probably counterbalances the inefficiency deriving from the country's relatively high consolidation and family ownership, as showed also by the result on HHI (Abdul-Majid et al., 2011). Finally, unlike most of the established empirical literature we find a positive, sizeable and significant effect of market discipline (MARD) on efficiency only for the Philippines, the rest of the sample being negative. This supports the view that for 
private monitoring to be effective the quality of information is crucial, and this is a bigger problem in developing countries.

There are several possible explanations to the negative or limited effectiveness of reregulation on efficiency. First, government intervention may intensify agency problems thus hindering the progress of cost performance. Secondly, institutional weaknesses may undermine the quality and effectiveness of official supervision. Most Asian economies lack trained and experienced regulators, and suffer from poor quality on-site supervision and ineffective law enforcement. In extreme cases supervisors might even abuse their powers to benefit some parties or extract bribes. Finally, as we said above, disclosure-based supervisory strategies will be less effective in developing countries given that informational asymmetries are large and the production of timely and accurate information is costlier. These potential negative effects of re-regulatory instruments should be carefully considered by policy makers when revising regulatory frameworks.

Turning to the other determinants of inefficiency, State banks are generally more efficient than their domestic private counterparts (except in China), whereas cooperatives, when they exist, less so. The difference between foreign and domestic private banks is mixed, confirming that no firm conclusion can be drawn about the prevalence of the home field vs. the global advantage effect discussed in the literature (Claessens and Van Horen, 2014). The degree of concentration also has a mixed effect. According to microeconomic theory, the effect of market concentration on cost efficiency is determined by two opposite factors: the negative effect of market power, which reduces the incentives to minimise costs; and the positive effect of scale economies. The former may well be the case of Malaysia, where a second round of consolidation in 2001-2004 initiated by major large-sized banks with overlapping market 
segmentation is likely to have raised profits rather than improved cost efficiency (AbdulMajid et al., 2011). The latter is instead probably the case of China where consolidation was dominated by small- and medium-sized banks trying to enjoy scale and scope economies to improve their competitiveness against the larger incumbents.

\subsection{The estimation of the meta-frontier}

Table 5 reports the main results from the estimation of the meta-frontier, along with the confidence intervals and standard errors derived from bootstrapping. Inputs and outputs elasticities have again the expected sign. As was the case for many country frontiers, fees and commissions $\left(q_{3}\right)$ are not significant. The convex pattern of the time trend suggests improvements of the meta-technology until about 2009 and a worsening thereafter. This finding is in line with that of Sun and Chang (2011) who analyse the period 1998-2008 and find a worsening of technology immediately after the crisis and improvements from around 2001, which is the starting point of our dataset. Better resources spent on risk control, new business initiatives and technological innovation might have contributed to this pattern of cost technology. Loan loss provisions (LLP) are very significant both statistically and economically at increasing costs; this is consistent with theoretical expectations especially given the efforts that some banks had to make to clean up their balance sheets after the crisis. VOroa and $C R$ have a cost reducing effect, in line with the interpretation provided before, although the former this time is not significant.

Finally, while financial deregulation significantly lowers costs, the positive effect of reregulation is not significant. This implies that if deregulation and re-regulation policies were to be carried out together the total net effect would be a positive reduction in total costs, which is good news from a regulator's point of view.

\section{Insert Table 5 here}

Page $\mid 27$ 
We can now turn our attention to the final part of the analysis which is the cross country comparison and in particular the identification of 'technical leaders', which we will define shortly.

As explained in Section 4.3 the distance of each bank from the meta-frontier, or metacost efficiency (Meta-CE), can be broken down into the product of two separate components: the country-specific cost efficiency $(C E)$ discussed before, and the technical gap ratio $(T G R)$. The $T G R$ is the distance between the country-specific frontier and the meta-frontier and therefore measures how advanced the technology of a particular bank or country is. We define as 'technical leader' a bank whose TGR score is at least $0.99^{13}$. These are the banks that push the meta-technology forward, or put otherwise the technological innovators across the region. Identifying these banks and their characteristics is one of the great advantages of the meta-frontier approach.

The top half of Table 6 reports for each country the median ${ }^{14} T G R, C E$ and Meta-CE scores across the whole 2001-2010 period. Figure 4 plots the yearly values of TGR and $C E$ for each country.

\section{Insert Table 6 here}

\section{Insert Figure 4 here}

Several interesting things can be observed from Table 6 and Figure 4. First of all, the country-specific efficiency levels are all quite high (all well above 90\%), and do not change much over time (median yearly changes range from the $-1.4 \%$ of Malaysia to the $+1.6 \%$ of Indonesia). High average levels are often found in country-specific studies, and the emphasis in such studies is usually more on the detailed performance of specific banks or groups of banks. As can be expected TGR levels are a lot lower, and

\footnotetext{
${ }^{13}$ Given the deterministic nature of the methodology, restricting the analysis to scores of exactly 1 would reduce the number of relevant observations quite significantly.

${ }^{14}$ Since these variables have very skewed distributions the median is preferred to the mean as a measure of central tendency.
}

Page $\mid 28$ 
their pattern varies a lot across the sample. China and Japan are the top performers, with the highest median scores of 0.92 and 0.91 respectively and (as we will see later) also the highest number of technical leaders. Japan suffers an early drop in performance around 2002, which corresponds to the implementation of its biggest changes in regulatory policy, and recovers thereafter. We attribute Japan's good performance to its wide ranging reforms - the so-called 'Financial Big Bang' that started in the late 1990s but continued well into the 2000s. This stimulated market-based mechanisms and increased banks' productivity (Aronson, 2013; Casu et al., 2015). Furthermore, banking innovations such as the IT revolution of the early 2000s, aimed at providing high-quality services, could have contributed to the superior technological performance of Japanese banks.

China displays an increasing trend in TGR, which overtakes Japan's in 2006 when the second round of policy changes, started in 2003, is finally in full swing (Klapper et al., 2014). It is during this period that the country accelerates what had previously been a fairly cautious programme of reforms, by further opening to foreign banks, adopting more modern corporate structures and creating a separate regulator (the CBRC), independent from the Central Bank. As was also shown in Table 1, and in line with Chan et al. (2014), this translated in improved performance. This cautious yet progressive approach clearly pays off in terms of performance and, as shown below, gives many Chinese private banks a leading position across the region.

Hong Kong's bimodal shape, with a fall in 2006-2007, corresponds initially to a loosening in regulation and then to the financial crisis which affected many of Hong Kong banks, most of which are foreign subsidiaries. Malaysia is the worst performer in the sample, and its pattern of $T G R$ worsens over time. Close to Malaysia are the Philippines, which however partly improve their performance over time. The poor 
performance of Malaysia can be ascribed to its increasingly stringent capital norms, and to the reduction in competition and efficiency brought about by higher concentration and by the adoption of prudential policies that restricted foreign bank entry and branching.

The lower half of Table 6 (Panel B) reports the main results from the analysis of technical leaders. These are the banks that create and push the best technology forward with a $T G R$ score of at least $0.99^{15}$. There are 77 technical leaders over the whole time period 2001-2010. Of these 45 are Chinese banks and 19 are Japanese banks, followed at some distance by 7 banks in Hong Kong and negligible numbers elsewhere. Chinese banks start to appear among the technical leaders in 2003 and in particular from 2006 onwards - corresponding to the fuller implementation of the reform process in the country. As Table 6 shows, private banks play a predominant role, accounting for $74 \%$ of the technical leaders; foreign banks follow with $18 \%$, cooperatives with $8 \%$ and State banks with $0 \%$. The strong implication is that State and possibly cooperative banks are not leaders in adopting or promoting technological innovation. Privatization policies and the opening to foreign bank entry are instead essential in promoting innovation in banking services and allowing spill-over effects across countries. This result is consistent with the findings of Luo et al. (2015) and is in line with the more recent analyses of the banking reforms in China reviewed in Section 3. More generally it supports that large theoretical literature that emphasizes the innovation-inducing effects of private ownership and foreign bank entry. Indeed while the proportion of foreign banks among technical leaders might seem relatively small it is actually consistent with the fact that

\footnotetext{
${ }^{15}$ Following the advice of an anonymous referee we have carried out two forms of sensitivity analysis of these results. First we tried a more generous threshold of 0.95 in the definition of technical leaders; then we progressively removed the top countries from the meta-frontier. The results are consistent to both modifications: Chinese and Japanese banks still account for about $90 \%$ of the technical leaders of the sample in the first case. In the second sensitivity test, the rankings of technical leaders are the same, with second tier banks becoming first tier banks as expected.
}

Page $\mid 30$ 
their overall proportion in Asian markets is generally low. Their presence at the top of the frontier, instead of the more prevalent state banks, is therefore particularly telling.

\section{Conclusions}

This study examines the impact of different deregulation and re-regulation policies on banks' cost efficiency and technology whilst controlling for ownership type, risk and concentration levels. The focus of the analysis has been on eight major Asian economies in the period 2001-2010, which saw renewed interest on policy reform following the Asian financial crisis. Due to technological heterogeneity we first estimate country-specific frontiers, then pool the data to estimate a meta-frontier and examine the factors that affect the meta-cost technology.

The country-specific frontiers show that deregulation of interest rates, removal of activities restrictions and foreign bank entry generally improve the efficiency with which banks perform their operations. This is especially so in countries where regulatory changes have been more pronounced, and less so where further scope for liberalization is more limited, suggesting possible non-linear effects. Capital markets deregulation is also consistently efficiency-enhancing. This finding underscores the importance of further liberalising banking systems in Asia if cost reduction is seen as key in improving financial access and growth. Bank re-regulation has instead a generally negative effect on banks efficiency, although less pronounced that the effect of deregulation. The negative effect of tighter capital requirements is possibly non-linear and kicks in only at higher levels of stringency. Stronger supervisory powers and market discipline affect efficiency negatively, contrary to the theoretical expectations of some of the literature. The overall negative effect on cost efficiency of re-regulatory policies might be linked to the level of development of the banking systems, and it should be carefully considered by policy makers when revising regulatory frameworks.

Page $\mid 31$ 
The results of the meta-frontier, which represents the best technology across the region, show that deregulation policies have a significant beneficial effect on technology, pushing the frontier ahead, while re-regulatory ones are not significant. Putting the two sets of results together it would seem that deregulation can help improve the technology of production as well as the efficiency with which banks apply such technology. Regulation instead, while not impeding technological improvements, impairs the efficiency with which banks can perform their operations.

Technological improvements, measured by the $T G R$ values, take place over time along with the positive impact of deregulation, slowing down later in concomitance with the impact of re-regulation policies and with the global financial crisis. These technological improvements are mainly led by Japan and China, and in particular by private and foreign banks; we find no state banks and very few cooperatives among the technology leaders, confirming the view that policies that promote privatization and foreign bank entry are key to innovation and efficiency.

Overall, the coexistence of deregulatory and re-regulatory frameworks observed in Asia has been beneficial for banks' cost performance in the past decade. However, there are signs of a slowing down of such performance in more recent years, which may be associated with the increasing emphasis on bank prudential re-regulation. These results highlight the importance of combining policies which aim to foster financial stability with policies which promote financial intermediation. 


\section{Appendix A}

Table A1 Variables specification

\begin{tabular}{|c|c|c|}
\hline Variable & Definition & Source \\
\hline \multicolumn{3}{|c|}{ Dependent Variable } \\
\hline$T C$ & $\begin{array}{l}\text { Total Cost }(T C)=\text { Interest Expenses + Operating } \\
\text { Expenses }\end{array}$ & Bankscope \\
\hline \multicolumn{3}{|c|}{ Determinants of the cost frontier } \\
\hline PL $\left(w_{i}\right)$ & $\begin{array}{l}\text { Price of Labour }=\text { Personnel Expenses } / \text { Total } \\
\text { Assets }\end{array}$ & Bankscope \\
\hline $\mathrm{PC}\left(w_{2}\right)$ & $\begin{array}{l}\text { Price of Capital }=(\text { Other Operating Expenses }+ \\
\text { Loan and other Impaired changes }) / \text { Total Assets }\end{array}$ & Bankscope \\
\hline $\mathrm{PF}\left(w_{3}\right)$ & $\begin{array}{l}\text { Price of Funds = Interest Expenses/ (Total } \\
\text { Deposits }+ \text { Money Market and Short-term funding } \\
+ \text { Other Funding+ Long-term Funding) }\end{array}$ & Bankscope \\
\hline $\mathrm{LN}\left(q_{l}\right)$ & $\begin{array}{l}\text { Net Loans = Gross Loans - Reserves for Impaired } \\
\text { Loans }\end{array}$ & Bankscope \\
\hline OEA $\left(q_{2}\right)$ & Other Earning Assets & Bankscope \\
\hline $\operatorname{NFC}\left(q_{3}\right)$ & Net Fees and Commissions & Bankscope \\
\hline \multicolumn{3}{|c|}{ Risk factors } \\
\hline $\mathrm{CR}$ & $\begin{array}{l}\text { Equity Capital Ratio = (Equity Capital }+ \text { Reserves }) \\
/(\text { Total Loans) }\end{array}$ & Bankscope \\
\hline VOroa & $\begin{array}{l}\text { Volatility of ROA = Standard Deviation of Return } \\
\text { on Assets }\end{array}$ & Bankscope \\
\hline LLP & $\begin{array}{l}\text { Loan Loss Provisions }=\text { Reserves for Impaired } \\
\text { Loans/Total Loans }\end{array}$ & Bankscope \\
\hline GDP & Annual GDP Growth Rate & $\begin{array}{l}\text { World } \\
\text { Development } \\
\text { Indicators (WDI) }\end{array}$ \\
\hline Dereg & $\begin{array}{l}\text { Deregulation indicator, average of the (normalised) } \\
\text { ACTR and CMD. }\end{array}$ & $\begin{array}{l}\text { (Barth et al., 2001, } \\
2003,2007,2012)\end{array}$ \\
\hline Rereg & $\begin{array}{l}\text { Re-regulation indicator, average of the (normalised) } \\
\text { CAPS, SUPP and MARD. }\end{array}$ & $\begin{array}{l}\text { (Barth et al., 2001, } \\
2003,2007,2012)\end{array}$ \\
\hline \multicolumn{3}{|c|}{ Determinants of inefficiency } \\
\hline ACTR & $\begin{array}{l}\text { Activities restrictions: the index measures the } \\
\text { degree to which banks are allowed to engage in fee- } \\
\text { based activities, and the degree of regulatory } \\
\text { restrictiveness on the mixing of banking and } \\
\text { commerce. The degree of restrictiveness for each } \\
\text { activity is measured on a scale from } 1 \text { to 4, } \\
\text { corresponding to 'prohibited' 'restricted', } \\
\text { 'permitted', and 'unrestricted'. The index is the } \\
\text { average scale across the activities. }\end{array}$ & $\begin{array}{l}\text { (Barth et al., 2001, } \\
2003,2007,2012)\end{array}$ \\
\hline
\end{tabular}


CMD Credit market deregulation: the index reflects the degree of banking market liberalization and it includes information on 4 categories: the ownership of banks, foreign bank competition, private sector credit and interest rate controls. Each category is assigned values between 0 to10, increasing with openness. The index is the average of the values across the categories.

CAPS Capital stringency: the index is based on the answers to the survey questions regarding the overall capital stringency. The values assigned to the index range from 0 to 7 , with higher values indicating greater capital stringency.

SUPP Supervisory powers: the index measures whether supervisory authorities can take specific actions to prevent and correct problems. A value of 1 is assigned to a 'yes' answer and a value of 0 to a 'no' answer. This variable is the sum of these assigned values which range from 0 to 15 , with higher values indicating greater supervisory power.

MARD Market discipline: the index captures the degree to which accurate information is disclosed to the public. The values assigned to the index range from 0 to 7 , with higher values indicating more transparency and hence greater private supervisory power.

State Dummy variable set equal to 1 if banks are ultimately owned by the State, and 0 otherwise;

Private Dummy variable set equal to 1 for domestic private banks, and 0 otherwise;

For Dummy variable set equal to 1 if banks are

(Barth et al., 2001, 2003, 2007, 2012) ultimately owned by foreign organisations or other parties, 0 otherwise;

Coop Dummy variable set equal to 1 if banks are credit Bankscope cooperatives and 0 otherwise.

HHI The Herfindahl - Hirschman Index. Values range Authors' from 0 to 1 , with higher values indicating greater calculations market concentration. 


\section{References:}

Abdul-Majid, M., Saal, D., Battisti, G. (2011), "Efficiency and Total Factor Productivity Change of Malaysian Commercial Banks", The Service Industries Journal, 13: 2117 2143.

Althammer, W., Haselmann, R. (2011), "Explaining Foreign Bank Entrance in Emerging Markets”, Journal of Comparative Economics, 39: 486-498.

Aronson, B. (2013), "Reassessing Japan's Big Bang: twenty Years of regulatory reform”, in Gerteis, C. and George T. (2013), Japan Since 1945: from Post-War to Post-Bubble, Bloomsbury, London; 165-188.

Ayadi, R., Ben Naceur, S., Casu, B., Quinn, B. (2016) Does Basel Compliance Matter for Bank Performance?” Journal of Financial Stability, 23:15-32.

Banker, R. D., Chang, H., Lee, S.Y. (2010,) "Differential Impact of Korean Banking System Reforms on Bank Productivity”, Journal of Banking \& Finance 34: 1450-1460.

Barth, J. R., Caprio, G., Levine, R. (2001, 2003, 2007, 2012), The Regulation and Supervision of Banks Around the World: A New Database, World Bank, Washington.

Barth, J. R., Caprio, G., Levine, R. (2004), "Bank Supervision and Regulation: What Works Best?” Journal of Financial Intermediation 13: 205-48.

Barth, J.R., Caprio, G., Levine, R. (2008) "Bank Regulations are Changing: For Better or Worse?”, Comparative Economics Studies, 50: 537-563.

Barth, J.R., Lin, C., Ma, Y., Seade J., Song F.M. (2013), “Do Bank Regulation, Supervision and Monitoring Enhance or Impede Bank Efficiency?" Journal of Banking and Finance 37: 2879-92.

Battese, G.E., Coelli, T.J. (1995), "A Model for Technical Inefficiency Effects in a Stochastic Frontier Production Function for Panel Data”, Empirical Economics, 20: 325-332.

Battese, G.E., Rao, D.S.P. (2002), "Technology Gap, Efficiency and a Stochastic Metafrontier Function”, International Journal of Business and Economics 1 (2): 1-7.

Battese, G.E., Rao, D.S.P., O’Donnell, C.J. (2004), “A meta-frontier Production Function for Estimation of Technical Efficiencies and Technology Gaps for Firms Operating Under Different Technologies”, Journal of Productivity Analysis 21: 91-103.

Bauer, P.W., Berger, A.N., Ferrier, G.D., Humphrey D.B. (1993), "Efficiency and Productivity Growth in US Banking”, in Fried, H.O., C.A.K. Lovell, and S.S. Schmidt (eds), The Measurement of Productive Efficiency: Techniques and Applications, Oxford University Press, Oxford; 386-413.

Beck, T., Demirgüc-Kunt, A., Levine, R. (2006), "Bank supervision and Corruption in 
Lending”, Journal of Monetary Economics 53: 2131-63.

Berger, A.N., Mester L.J. (2003), "Explaining the dramatic changes in performance of US banks: technological change, deregulation, and dynamic changes in competition," Journal of Financial Intermediation, 12, 57-95.

Bliss, R.R., Flannery M.J. (2002), "Market Discipline in the Governance of U.S. Bank Holding Companies: Monitoring versus Influence”, European Finance Review 6: 419437.

Casu B., Ferrari A., Zhao T., (2013), "Regulatory reform and productivity change in Indian banking”, Review of Economics and Statistics, 95(3): 1066-1077.

Casu, B, Girardone, C., Molyneux, P. (2015), "Banking in Japan” in Casu, B, Girardone, C., Molyneux, P. (2015), Introduction to Banking; Pearson, London. Ch. 16; 527-553.

Chaffai, M.E., Dietsch, M., Lozano-Vivas, A. (2001), "Technological and Environmental Differences in the European Banking Industries", Journal of Financial Services Research 19(2/3): 147-162.

Chan, S., Abd Karim, M., Burton, B., Aktan, B. (2014), "Efficiency and risk in commercial banking: empirical evidence form East Asian countries", The European Journal of Finance, 20(12): 1114-1132.

Chen, X., Skully, M., Brown, K. (2005), "Banking Efficiency in China: Application of DEA to Pre- and Post-deregulation eras: 1993-2000”, China Economic Review 16, 229-245.

Chortareas, G., Girardone, C., Ventouri, A. (2012), "Bank Supervision, Regulation and Efficiency: Evidence from the European Union”, Journal of Financial Stability 8(4): 292-302.

Claessens, S., Van Horen, N. (2014), "Foreign Banks: Trends and Impact", Journal of Money Credit and Banking, 46: 295-326.

Claeys, S., Hainz, C. (2014), "Modes of Foreign Bank Entry and Effects on Lending Rates: Theory and evidence", Journal of Comparative Economics, 42: 160-177.

Clarke G., Cull, R., Martinez Peira, M.S., Sanchez, S.M. (2003), "Foreign bank entry: experience, implications for developing economies and agenda for further research", The World Bank Research Observer, 18(1); 1-41.

Davutyan, N., Yildirim, C. (2015), "Efficiency in Turkish banking: post-restructuring evidence", The European Journal of Finance. Published online, 1-22.

Delis, M. D., Molyneux, P., Pasiouras, F. (2011), "Regulations and Productivity Growth in Banking; Evidence from Transition Economies", Journal of Money, Credit and Banking, 43(4): 735-764.

Demirgüç-Kunt, A., Laeven, L., Levine, R. (2004), "Regulations, Market Structure, Page $\mid 36$ 
Institutions, and the Cost of Financial Intermediation”, Journal of Money, Credit and Banking, 36 (3): 563-583.

Detragiache, E., Gupta, P. (2006), "Foreign Banks in Emerging Market Crises: Evidence for Malaysia”, Journal of Financial Stability, 2(3): 217-242.

Dietsch, M., Lozano-Vivas, A. (2000), "How the Environment Determines Banking Efficiency: A Comparison between French and Spanish Industries”, Journal of Banking \& Finance 24: 985-1004.

Fu, X., Heffernan, S. (2009), "The effects of reform on China's bank structure and performance”, Journal of Banking \& Finance 33: 39-52.

Gilbert, R.A., Wilson, P.W. (1998), "Effects of Deregulation on the Productivity of Korean Banks", Journal of Economics \& Business 50: 155-155.

Glass, J., McKillop, D., Quinn, B., Wilson, J. (2013), "Cooperative bank efficiency in Japan: a parametric distance function analysis”, The European Journal of Finance, 20(3): 291-317.

Hasan, I., Marton, K. (2003), "Development and Efficiency of the Banking Sector in a Transitional Economy: Hungarian Experience”, Journal of Banking \& Finance 27: 2249-2271.

Havrylchyk, O. (2006), "Efficiency of the Polish Banking Industry: Foreign versus Domestic Banks”, Journal of Banking \& Finance 30: 1975-1996.

Haw, I. M., Ho, S.S.M, Hu, B., Wu, D. (2010), "Concentrated Control, Institutions, and Banking Sector; An International Study”, Journal of Banking \& Finance 34: 485-497.

He, L., Fan, X. (2004), "Foreign Banks in Post-WTO China: An Intermediate Assessment”, China and the World Economy, 12: 3-16.

Hughes, J., Mester, L. (2013), "Who Said Large Banks Don’t Experience Scale Economies? Evidence from a Risk-Return-Driven Cost Function”, Journal of Financial Intermediation, 22: 559-585.

Isik, I., and M.K. Hassan (2002), "Technical, Scale and Allocative Efficiencies of Turkish Banking Industry", Journal of Banking \& Finance 26: 719-766.

Jayaratne, J., Strahan, P.E. (1996), "The Finance-Growth Nexus: Evidence from Bank Branch Deregulation”, Quarterly Journal of Economics, 111(3): 639-670.

Jeon, Y., Miller, S. (2005), "Performance of Domestic and Foreign Banks: the Case of Korea and the Asian Financial Crisis”, Global Economic Review 34: 145-165.

Jeon, Y., Miller, S., Natke, P. (2006), "Do Foreign Banks Operations Provide a Stabilizing Influence in Korea?”, The Quarterly Review of Economics and Finance, 46-1: 86-109. 
Jiang, C., Yao, S., Zhao, Z. (2009), "The effects of governance changes on bank efficiency in

China: A stochastic distance function approach", China Economic Review, 20: 717731.

Kano, M., Tsutsui, Y. (2003), "Geographical Segmentation in Japanese Bank Loan Markets", Regional Science and Urban Economics, 33: 157-174.

Klapper, L., Martinez-Peira, M.S., Zia, B. (2014), "Banking in the Developing Nations of Asia” in Berger, A.N., Molyneux, P., Wilson, J.O.S. (2014), The Oxford Handbook of Banking, Oxford University Press, Oxford; ch. 38, 941-962.

Koutsomanoli, F. A., Margaritis, D., Staikouras, C. (2009), "Efficiency and Productivity Growth in the Banking Industry of Central and Eastern Europe", Journal of Banking \& Finance, 33(3): 557-567.

Kumbhakar, S. C., Lovell, C.A.K. (2000), Stochastic Frontier Analysis, Cambridge University Press. Cambridge.

Kumbhakar, S.C., Sarkar, S. (2003), "Deregulation, Ownership, and Productivity Growth in the Banking Industry: Evidence from India”, Journal of Money, Credit, and Banking 35(3): 403-424.

Laeven, L. (2005), "Banking Sector Performance in East Asian Countries: the Effects of Competition, Diversification and Ownership” World Bank, Washington.

Leightner, J.E., Lovell, C.A.K. (1998), "The Impact of Financial Liberalisation on the Performance of Thai Banks”, Journal of Economics and Business 50:115-131.

Lin, X., Zhang, Y. (2009), "Bank ownership reform and bank performance in China”, Journal of Banking \& Finance 33: 20-29.

Luo, D., Dong, Y., Armitage, S., Hou, W. (2015), “The impact of foreign bank penetration on the domestic banking sector: new evidence from China", The European Journal of Finance, mimeo. Published online, 1-29.

Mester, L..J. (1996), “A Study of Bank Efficiency Taking into Account Risk-preferences”, Journal of Banking \& Finance 20: 1025-1045.

Naaborg, I., Lensink, R. (2008), "Banking in transition economies: does foreign ownership enhance profitability?”, The European Journal of Finance 14 (7): 545-562.

Pasiouras, F., Tanna, S., Zopounidis, C. (2009), "The Impact of Banking Regulations on Banks' Cost and Profit Efficiency; Cross-country Evidence”, International Review of Financial analysis 18: 294-302.

Shleifer, A., Vishny, R. (1998), The Grabbing Hand; Government Pathologies and Their Cures, Harvard University Press, Cambridge.

Stigler, G. J. (1971), “The Theory of Economic Regulation”, The Bell Journal of Page $\mid 38$ 
Economics and Management Science 2: 3-21.

Sun, L., Chang, T.P. (2011), “A Comprehensive Analysis of the Effects of Risk Measures on Bank Efficiency: Evidence from Emerging Asian Countries” Journal of Banking \& Finance 35: 1727-1735.

Thakor, A. (1996), “The Design of Financial Systems: An Overview”, Journal of Banking \& Finance 20(5): 917-948.

Thangavelu, S. M., Findlay, C. (2013), "Bank efficiency, regulation and response to crisis of financial institutions in selected Asian countries”, in Thangavelu S.M., Chongvilaivan, A. (eds) Real and Financial Integration in Asia, Routledge, London. Ch 8; 133-150.

Williams, J., Nguyen, N. (2005), "Financial Liberalisation, Crisis and Restructuring: a Comparative Study of Bank Performance and Bank Governance in South East Asia”, Journal of Banking \& Finance 29: 2119-2154.

Zhao, T., Casu, B., Ferrari, A. (2010), "The Impact of Regulatory Reforms on Cost Structure, Ownership and Competition in Indian Banking”, Journal of Banking \& Finance 34: 246-254. 
Table 1: Selected performance measures 2001-2010

This table illustrates selected bank performance indicators for the countries in our sample: CN (China); HK (Hong Kong); ID (Indonesia); IN (India); JP (Japan); MY (Malaysia); PH (Philippines); TH (Thailand). South Asia illustrates the average for the region. EMU illustrates the average for the euro zone and US illustrates the average for the United States. NIM is the Net Interest Margin; CAR is the Capital to Assets Ratio; NPL is Non-Performing Loans; ROA is the Return of Assets; CIR is the Cost-toIncome Ratio. The values reported are from the Global Financial Development database of the World Bank.

\begin{tabular}{|c|c|c|c|c|c|c|}
\hline Country & Year & NIM & CAR & NPL & ROA & CIR \\
\hline \multirow[t]{3}{*}{$\mathrm{CN}$} & 2001 & 2.15 & 4.1 & 29.8 & 0.38 & 64.2 \\
\hline & 2005 & 2.30 & 4.4 & 8.6 & 0.47 & 43.9 \\
\hline & 2010 & 2.49 & 6.1 & 1.1 & 1.12 & 30.9 \\
\hline \multirow[t]{3}{*}{ HK } & 2001 & 0.86 & 9.8 & 6.5 & 0.2 & 30.3 \\
\hline & 2005 & 1.40 & 10.3 & 1.4 & 1.55 & 54.3 \\
\hline & 2010 & 2.12 & 13.3 & 0.8 & 1.21 & 55.8 \\
\hline \multirow[t]{3}{*}{ ID } & 2001 & 3.66 & 5.2 & 31.9 & 0.43 & 75.9 \\
\hline & 2005 & 5.81 & 9.8 & 7.4 & 1.59 & 56.1 \\
\hline & 2010 & 6.64 & 11.4 & 2.6 & 2.14 & 39.1 \\
\hline \multirow[t]{3}{*}{ IN } & 2001 & 3.04 & 5.3 & 11.4 & 0.72 & 63.0 \\
\hline & 2005 & 3.38 & 6.4 & 5.2 & 0.98 & 53.0 \\
\hline & 2010 & 3.34 & 7.1 & 2.4 & 1.07 & 36.2 \\
\hline \multirow[t]{3}{*}{ JP } & 2001 & 1.26 & 3.9 & 8.4 & -0.69 & 59.4 \\
\hline & 2005 & 1.14 & 4.9 & 1.8 & 0.5 & 53.8 \\
\hline & 2010 & 1.11 & 4.8 & 1.8 & 0.25 & 55.2 \\
\hline \multirow[t]{3}{*}{ MY } & 2001 & 3.54 & 8.3 & 17.8 & 0.77 & 43.6 \\
\hline & 2005 & 3.50 & 7.7 & 9.6 & 1.49 & 35.2 \\
\hline & 2010 & 2.99 & 9.1 & 3.4 & 1.35 & 37.4 \\
\hline \multirow[t]{3}{*}{$\mathrm{PH}$} & 2001 & 2.28 & 13.6 & 27.7 & 0.18 & 93.7 \\
\hline & 2005 & 4.82 & 12.0 & 10.0 & 1.36 & 64.6 \\
\hline & 2010 & 3.99 & 11.7 & 3.8 & 1.41 & 51.1 \\
\hline \multirow[t]{3}{*}{$\mathrm{TH}$} & 2001 & 1.82 & 8.9 & 11.5 & 1.45 & 75.5 \\
\hline & 2005 & 3.04 & 8.9 & 9.1 & 1.35 & 49.9 \\
\hline & 2010 & 3.26 & 11.3 & 3.9 & 1.22 & 44.0 \\
\hline South & 2001 & 3.27 & 3.8 & 23.4 & 0.65 & 53.9 \\
\hline \multirow[t]{2}{*}{ Asia } & 2005 & 4.12 & 7.2 & 6.8 & 1.17 & 60.8 \\
\hline & 2010 & 5.34 & 9.3 & 5.2 & 1.15 & 48.9 \\
\hline \multirow[t]{3}{*}{ EMU } & 2001 & 2.36 & 5.9 & 2.30 & 0.50 & 63.7 \\
\hline & 2005 & 2.24 & 6.2 & 2.50 & 0.80 & 58.8 \\
\hline & 2010 & 1.68 & 5.9 & 2.20 & 0.30 & 64.7 \\
\hline \multirow[t]{3}{*}{ US } & 2001 & 3.84 & 9.00 & 1.30 & 1.13 & 58.99 \\
\hline & 2005 & 3.49 & 10.3 & 0.70 & 1.30 & 58.31 \\
\hline & 2010 & 3.82 & 12.7 & 4.40 & 0.65 & 58.59 \\
\hline
\end{tabular}

Page $\mid 40$ 


\section{Table 2 Sample descriptive statistics, 2001-2010}

This table reports descriptive statistics for the variables used in the empirical analysis. The countries in our sample are denoted as follows: CN (China); HK (Hong Kong); ID (Indonesia); IN (India); JP (Japan); MY (Malaysia); PH (Philippines); TH (Thailand). For the definition and construction of the variables see Appendix A. Notes: a) Average total assets, total cost and outputs (rows 2-6): values are reported in \$mil, deflated using 2005 as base year. b) Average input prices (rows 7-9), values are reported in \$10,000. c) GDP growth (row 10) is the average \% yearly value. d) Risk indicators (rows 11-13) are median \% values. e) Dereg (row 16) is the aggregate deregulatory measure, computed as the average of rows 14-15. Rereg (row 20) is the agoregate re-regulatory measure, computed as the average of rows 17-19. f) All regulatory indices are scaled by the maximum possible value of each group to ensure they are all bound between 0 and 1 to ease comparison. Their values in the table are reported in \%. $g$ ) Ownership is measured as the \% of total assets of each category.

\begin{tabular}{|c|c|c|c|c|c|c|c|c|c|c|}
\hline Row & Categories & Variables & $\mathbf{C N}$ & HK & ID & IN & $\mathbf{J P}$ & MY & PH & TH \\
\hline 1 & Obs. & Tot. banks & 615 & 251 & 435 & 555 & 1080 & 231 & 261 & 148 \\
\hline 2 & Average Size & Tot. Asset (TA) & 66365 & 33032 & 2965 & 13674 & 62256 & 10791 & 2572 & 14767 \\
\hline 3 & Dep var & Tot. Cost $(\boldsymbol{T C})$ & 1890 & 862 & 269 & 953 & 983 & 443 & 161 & 624 \\
\hline 4 & \multirow{3}{*}{ Outputs $(\boldsymbol{q})$} & Net Loans $(\boldsymbol{L N})$ & 34224 & 13663 & 1310 & 7642 & 35228 & 6388 & 1114 & 9627 \\
\hline 5 & & Other Earning Assets $(\boldsymbol{O E A})$ & 26864 & 16317 & 1277 & 4549 & 23983 & 1453 & 1083 & 4000 \\
\hline 6 & & Net Fees \& Commissions (NFC) & 275 & 337 & 39 & 175 & 249 & 107 & 44 & 183 \\
\hline 7 & \multirow{3}{*}{ Input prices $(\boldsymbol{w})$} & Price of Labor $(\boldsymbol{P L})$ & 0.501 & 0.77 & 1.42 & 1.11 & 0.57 & 0.69 & 1.55 & 0.81 \\
\hline 8 & & Price of Capital $(\boldsymbol{P C})$ & 1.06 & 0.84 & 2.27 & 1.62 & 0.99 & 1.16 & 3.11 & 1.87 \\
\hline 9 & & Price of Funds $(\boldsymbol{P F})$ & 1.96 & 2.17 & 6.05 & 5.35 & 0.25 & 2.60 & 3.85 & 2.21 \\
\hline 10 & Macro $(\boldsymbol{G D P})$ & GDP growth & 10.9 & 4.0 & 5.2 & 7.2 & 0.7 & 4.5 & 4.8 & 4.3 \\
\hline 11 & Risk indicators $(\boldsymbol{R K})$ & Equity Capital Ratio (CR) & 7.62 & 14.90 & 15.88 & 10.75 & 6.59 & 13.55 & 20.54 & 13.11 \\
\hline
\end{tabular}

Page | 41 


\begin{tabular}{|c|c|c|c|c|c|c|c|c|c|c|}
\hline 12 & & Volatility of ROA (VOroa) & 0.36 & 0.36 & 0.62 & 0.31 & 0.26 & 0.46 & 0.52 & 0.62 \\
\hline 13 & & Loan Loss Provisions $(\boldsymbol{L L P})$ & 1.78 & 1.03 & 2.64 & 1.49 & 1.51 & 3.85 & 5.86 & 5.00 \\
\hline 14 & \multirow{3}{*}{ Dereg. indicators } & Activities restrictions $(\boldsymbol{A C T R})$ & 34.8 & 91.6 & 36.6 & 51.9 & 55.0 & 56.9 & 81.3 & 49.3 \\
\hline 15 & & Credit market deregulation $(\boldsymbol{C M D})$ & 66.1 & 95.1 & 74.8 & 67.3 & 80.9 & 82.5 & 82.8 & 81.3 \\
\hline 16 & & Deregulation (Dereg) & 50.5 & 93.4 & 55.7 & 59.6 & 68.0 & 69.7 & 82.1 & 65.3 \\
\hline 17 & \multirow{4}{*}{$\begin{array}{c}\text { Rereg. } \\
\text { indicators }\end{array}$} & Capital stringency $(\boldsymbol{C A P S})$ & 24.1 & 60.5 & 39.0 & 59.0 & 37.6 & 38.2 & 63.0 & 43.2 \\
\hline 18 & & Supervisory powers $(\boldsymbol{S U P P})$ & 69.2 & 53.2 & 78.4 & 63.6 & 69.0 & 67.1 & 79.6 & 66.6 \\
\hline 19 & & Market discipline (MARD) & 75.4 & 83.0 & 63.7 & 60.7 & 63.6 & 74.9 & 74.0 & 74.6 \\
\hline 20 & & Reregulation (Rereg) & 56.2 & 65.6 & 60.3 & 61.1 & 56.8 & 60.1 & 72.2 & 61.5 \\
\hline 21 & \multirow{4}{*}{ Ownership } & State (State) & 68.0 & 0.00 & 51.0 & 73.8 & 0.00 & 22.9 & 8.3 & 35.0 \\
\hline 22 & & Private (Private) & 29.4 & 20.4 & 18.4 & 20.9 & 100 & 54.6 & 90.43 & 60.0 \\
\hline 23 & & Foreign (For) & 1.1 & 79.6 & 30.6 & 4.48 & 0.00 & 22.5 & 1.25 & 5.00 \\
\hline 24 & & Cooperative (Coop) & 1.5 & 0.00 & 0.00 & 0.82 & 0.00 & 0.00 & 0.02 & 0.00 \\
\hline 25 & Concentr. & Herfindahl Index (HHI) & 12.91 & 25.89 & 10.36 & 7.20 & 7.22 & 9.55 & 9.28 & 10.54 \\
\hline
\end{tabular}

Page | 42 


\section{Table 3 Changes in the regulatory environment - selected indicators}

This table illustrates selected bank regulation indicators for the countries in our sample: CN (China); HK (Hong Kong); ID (Indonesia); IN (India); JP (Japan); MY (Malaysia); PH (Philippines); TH (Thailand). ACT is Activity Restrictions; CMD is Credit Market Deregulation; Dereg is an aggregate deregulation index. The higher the index value, the more deregulated the banking system. CAPS is an indicator of capital stringency; SUPP indicates supervisory powers; MARD indicates market discipline; Rereg is an aggregate re-regulation index. Higher values of the index indicate more stringent regulation. The values reported are from the Bank Regulation and Supervision around the World surveys carried out by the World Bank, apart from the indicator of Credit Market Deregulation, which is from the Index of Economic Freedom Database complied by the Heritage Foundation.

\begin{tabular}{|c|c|c|c|c|c|c|c|c|}
\hline \multirow[b]{2}{*}{ Country } & \multirow[b]{2}{*}{ Year } & \multicolumn{3}{|c|}{ Deregulation indicators } & \multicolumn{4}{|c|}{ Reregulation indicators } \\
\hline & & $A C T R$ & CMD & Dereg & CAPS & SUPP & MARD & Rereg \\
\hline \multirow[t]{4}{*}{$\mathrm{CN}$} & 2001 & 37.5 & 60.0 & 49.0 & 8.3 & 66.7 & 63.6 & 46.2 \\
\hline & 2004 & 37.5 & 64.0 & 51.0 & 8.3 & 66.7 & 63.6 & 46.2 \\
\hline & 2007 & 31.3 & 70.0 & 51.0 & 16.7 & 71.0 & 73.0 & 53.6 \\
\hline & 2010 & 37.5 & 66.0 & 52.0 & 66.7 & 69.7 & 100.0 & 78.8 \\
\hline \multirow[t]{4}{*}{ HK } & 2001 & 87.5 & 98.0 & 93.0 & 66.7 & 54.8 & 83.0 & 68.2 \\
\hline & 2004 & 87.5 & 95.0 & 91.0 & 66.7 & 54.8 & 83.0 & 68.2 \\
\hline & 2007 & 93.8 & 95.0 & 94.0 & 41.7 & 46.7 & 83.0 & 57.1 \\
\hline & 2010 & 100.0 & 92.0 & 96.0 & 75.0 & 60.0 & 83.0 & 72.7 \\
\hline \multirow[t]{4}{*}{ ID } & 2001 & 37.5 & 78.0 & 58.0 & 25.0 & 80.6 & 58.3 & 54.7 \\
\hline & 2004 & 37.5 & 66.0 & 52.0 & 25.0 & 80.6 & 58.3 & 54.7 \\
\hline & 2007 & 25.0 & 82.0 & 53.0 & 41.7 & 83.9 & 67.0 & 64.2 \\
\hline & 2010 & 56.3 & 77.0 & 67.0 & 75.0 & 67.7 & 74.0 & 72.2 \\
\hline \multirow[t]{4}{*}{ IN } & 2001 & 62.5 & 61.0 & 62.0 & 41.7 & 48.4 & 54.5 & 48.2 \\
\hline & 2004 & 50.0 & 70.0 & 60.0 & 50.0 & 64.5 & 55.0 & 56.5 \\
\hline & 2007 & 56.3 & 71.0 & 64.0 & 58.3 & 67.7 & 63.0 & 63.0 \\
\hline & 2010 & 43.8 & 66.0 & 55.0 & 91.7 & 61.9 & 74.0 & 75.9 \\
\hline \multirow[t]{3}{*}{$\mathrm{JP}$} & 2001 & 43.8 & 84.0 & 64.0 & 41.7 & 64.5 & 50.0 & 52.1 \\
\hline & 2004 & 56.3 & 77.0 & 67.0 & 41.7 & 69.0 & 63.0 & 57.9 \\
\hline & 2007 & 56.3 & 85.0 & 71.0 & 33.3 & 70.0 & 67.0 & 56.8 \\
\hline
\end{tabular}




\begin{tabular}{l|l|lll|llll} 
& 2010 & 56.3 & 77.0 & 66.0 & 33.3 & 70.0 & 67.0 & 56.8 \\
\hline MY & 2001 & 62.5 & 77.0 & 70.0 & 16.7 & 76.7 & 75.0 & 56.1 \\
& 2004 & 56.3 & 77.0 & 67.0 & 16.7 & 64.5 & 78.0 & 53.1 \\
& 2007 & 56.3 & 91.0 & 74.0 & 50.0 & 71.0 & 71.0 & 64.0 \\
& 2010 & 56.3 & 85.0 & 71.0 & 75.0 & 65.2 & 74.0 & 71.4 \\
\hline PH & 2001 & 81.3 & 88.0 & 85.0 & 50.0 & 77.4 & 71.7 & 66.4 \\
& 2004 & 81.3 & 79.0 & 80.0 & 50.0 & 80.6 & 66.0 & 65.5 \\
& 2007 & 81.3 & 84.0 & 83.0 & 66.7 & 82.1 & 80.0 & 76.3 \\
& 2010 & 81.3 & 82.0 & 82.0 & 91.7 & 74.0 & 83.0 & 82.9 \\
\hline TH & 2001 & 68.8 & 78.0 & 73.0 & 33.3 & 73.3 & 65.8 & 57.5 \\
& 2004 & 50.0 & 75.0 & 63.0 & 25.0 & 63.3 & 73.0 & 53.8 \\
& 2007 & 43.8 & 86.0 & 65.0 & 41.7 & 64.5 & 83.0 & 63.1 \\
& 2010 & 50.0 & 82.0 & 66.0 & 83.3 & 74.0 & 67.0 & 74.8 \\
\hline
\end{tabular}

Page | 44 


\section{Table 4 Summary results from the country-specific stochastic frontier estimations}

This table reports the results of the country-specific stochastic frontier estimations. The countries in our sample are denoted as follows: CN (China); HK (Hong Kong); ID (Indonesia); IN (India); JP (Japan); MY (Malaysia); PH (Philippines); TH (Thailand). For the definition and construction of the variables see Appendix A. T and $T^{2}$ model the quadratic time trend. All regulatory indices are scaled by the maximum possible value of each group to ensure they are all bound between 0 and 1 . Each marginal effect is calculated as $\left(\partial C E / \partial Z_{i}\right)$, it is evaluated at the sample mean of $Z$ and it measures the \% change of bank cost efficiency due to a unit change in $z$. A positive sign therefore indicates that the variable increases cost efficiency, and viceversa.

\begin{tabular}{|c|c|c|c|c|c|c|c|c|c|}
\hline \multicolumn{10}{|c|}{ Frontier estimation } \\
\hline Country & & $\mathrm{CN}$ & HK & ID & IN & $\mathrm{JP}$ & MY & $\mathrm{PH}$ & $\mathrm{TH}$ \\
\hline Constant & $a_{0}$ & $1.888 * * *$ & $1.725^{*}$ & 0.583 & $1.137 * * *$ & $0.856 * * *$ & $3.971 * * *$ & -0.823 & 0.355 \\
\hline GDP_growth & $\vartheta$ & 0.004 & 0.006 & $0.030 * *$ & -0.0003 & $0.001 *$ & 0.003 & 0.001 & -0.003 \\
\hline $\mathrm{T}$ & $\eta_{1}$ & -0.011 & -0.031 & $0.020 *$ & -0.0025 & $-0.001 * * *$ & $0.040 * *$ & $0.054 * * *$ & $-0.037 * * *$ \\
\hline $\mathrm{T}^{2}$ & $\eta_{2}$ & 0.000 & 0.002 & $-0.003 * *$ & 0.000 & $0.001 * * *$ & -0.002 & $-0.004 * * *$ & $0.003^{* *}$ \\
\hline CR & $\mathrm{Y}_{1}$ & $-0.385 * * *$ & $-0.326 * * *$ & $-0.676 * * *$ & $-0.055 * * *$ & $-0.215 * * *$ & $0.304 * * *$ & $0.065 * * *$ & 0.044 \\
\hline VOroa & $\mathrm{V}_{2}$ & $-2.597 * *$ & -0.081 & -0.100 & $-0.953^{*}$ & $-0.202 * *$ & -0.783 & -0.128 & $1.334 * * *$ \\
\hline LLP & $\mathrm{Y}_{3}$ & $0.546^{* * *}$ & 0.018 & 0.053 & $0.246 * * *$ & $0.282 * * *$ & $0.696^{* *}$ & $0.714 * * *$ & 0.026 \\
\hline Dereg & $\theta_{1}$ & $-1.204 * *$ & 0.147 & $0.463 * *$ & 0.043 & $0.070 * *$ & 0.244 & $2.262 * * *$ & -0.294 \\
\hline Rereg & $\theta_{2}$ & -0.005 & 0.054 & 0.193 & 0.066 & $0.208 * * *$ & -0.144 & -0.199 & -0.037 \\
\hline Wald Test (1) & & $2287.045^{* * *}$ & $1318.009 * * *$ & $781.811 * * *$ & $755.428 * * *$ & $7050.064 * * *$ & $526.698 * * *$ & $919.485 * * *$ & $2036.998 * * *$ \\
\hline \multicolumn{10}{|c|}{ Input elasticities } \\
\hline dlntc/dlnw1 & & $0.154 * * *$ & $0.209 * * *$ & $0.165 * * *$ & $0.146^{* * *}$ & $0.320 * * *$ & $0.160 * * *$ & $0.239 * * *$ & $0.182 * * *$ \\
\hline $\mathrm{d} \operatorname{lntc} / \mathrm{d} \ln w 2$ & & $0.324 * * *$ & $0.263 * * *$ & $0.264 * * *$ & $0.202 * * *$ & $0.550 * * *$ & $0.268 * * *$ & $0.302 * * *$ & $0.387 * * *$ \\
\hline dlntc/dlnw3 & & $0.523 * * *$ & $0.528 * * *$ & $0.571 * * *$ & $0.652 * * *$ & $0.129 * * *$ & $0.572 * * *$ & $0.459 * * *$ & $0.431 * * *$ \\
\hline \multicolumn{10}{|c|}{ Output elasticities } \\
\hline $\mathrm{d} \ln t c / d \ln Q 1$ & & $0.626 * * *$ & 0.526 *** & $0.568 * * *$ & $0.603 * * *$ & $0.673 * * *$ & $0.629 * * *$ & $0.546^{* * *}$ & $0.770 * * *$ \\
\hline $\mathrm{d} \ln t c / \mathrm{d} \ln \mathrm{Q} 2$ & & $0.371 * * *$ & $0.477 * * *$ & $0.423 * * *$ & $0.401 * * *$ & $0.321 * * *$ & $0.334 * * *$ & $0.427 * * *$ & $0.259 * * *$ \\
\hline
\end{tabular}

Page | 45 


\begin{tabular}{|c|c|c|c|c|c|c|c|c|}
\hline $\mathrm{d} \ln t c / d \ln Q 3$ & $0.007 * * *$ & 0.001 & 0.008 & -0.005 & $0.003 * * *$ & 0.019 & $0.039 * *$ & -0.002 \\
\hline Scales economies & 1.004 & 1.004 & 0.999 & 0.999 & 0.998 & 0.982 & 1.012 & 1.027 \\
\hline
\end{tabular}

Inefficiency determinants: Marginal effects

\begin{tabular}{|c|c|c|c|c|c|c|c|c|c|}
\hline & & $\mathrm{CN}$ & HK & ID & IN & JP & MY & $\mathrm{PH}$ & TH \\
\hline ACTR & $\delta_{1}$ & -0.003 & $0.0001 * * *$ & $0.017 * * *$ & 0.056 & $0.015^{* * *}$ & 0.010 & - & $-0.021 * *$ \\
\hline CMD & $\delta_{2}$ & -0.040 & $-0.001 * * *$ & $0.089 * *$ & $0.051 * * *$ & $0.023 * * *$ & $0.064 * *$ & $0.182 * *$ & $0.014 * *$ \\
\hline CAPS & $\delta_{3}$ & -0.008 & 0.0000 & $-0.017 * * *$ & $-0.013^{* *}$ & $0.037 * * *$ & $-0.030 * *$ & $-0.203^{*}$ & -0.002 \\
\hline SUPP & $\delta_{4}$ & -0.006 & $0.0001 * * *$ & $-0.029 * * *$ & $-0.188^{*}$ & $-0.014 * * *$ & $0.053 * * *$ & $-0.236 * *$ & -0.007 \\
\hline MARD & $\delta_{5}$ & -0.009 & & $-0.023 * * *$ & -0.005 & $-0.008 * * *$ & $-0.038 * *$ & $0.263^{*}$ & $-0.044 * *$ \\
\hline STATE & $\delta_{6}$ & $-0.002 *$ & & $0.004 * *$ & $0.007 *$ & - & $0.027 * * *$ & 0.000 & $0.003 * *$ \\
\hline FOR & $\delta_{7}$ & 0.001 & $0.0001^{* * *}$ & $-0.001 *$ & $-0.013^{* *}$ & - & $-0.019 * * *$ & $-0.003^{*}$ & $0.001 * *$ \\
\hline COOP & $\delta_{8}$ & -0.001 & & - & $-0.007 *$ & - & & 0.002 & \\
\hline $\mathrm{HHI}$ & $\delta_{9}$ & $0.267 *$ & $0.001 * * *$ & $-0.041 * * *$ & $-0.376^{*}$ & $0.038 * * *$ & $-0.033 * *$ & $-0.246^{*}$ & $0.092 *$ \\
\hline $\mathrm{T}$ & $\delta_{10}$ & 0.003 & $-0.0001 * * *$ & $0.005 * * *$ & $-0.003 * * *$ & $0.0004 * * *$ & $-0.014 * * *$ & $0.007 * *$ & $-0.001 * * *$ \\
\hline $\mathrm{T} 2$ & $\delta_{11}$ & -0.000 & $0.0000 * * *$ & $-0.0004 * *$ & $0.0002 * *$ & 0.0000 & $0.001 * * *$ & $0.0003 * * *$ & $0.0002 * * *$ \\
\hline
\end{tabular}

Page | 46 


\section{Table 5. Main results from the estimation of the Meta-frontier}

This table reports the results of the meta-frontier. The countries in our sample are denoted as follows: CN (China); HK (Hong Kong); ID (Indonesia); IN (India); JP (Japan); MY (Malaysia); PH (Philippines); TH (Thailand). Dereg is the aggregate index of deregulatory measures, computed as the average of the individual indices. Rereg is the aggregate index of re-regulatory measures, computed as the average of the individual indices. For the definition and construction of the variables see Appendix $A$.

\begin{tabular}{lllll}
\hline Variable & & Coef & Std. Err & t-ratio \\
\hline GDP growth & $\vartheta$ & -0.001 & 0.003 & 0.33 \\
T & $\eta_{1}$ & -0.017 & 0.012 & -1.42 \\
TT & $\eta_{2}$ & 0.001 & 0.001 & 1.00 \\
CR & $\gamma_{1}$ & -0.464 & 0.065 & -7.14 \\
VoRoa & $\gamma_{2}$ & -0.975 & 0.934 & -1.04 \\
LLP & $\gamma_{3}$ & 0.646 & 0.158 & 4.09 \\
Dereg & $\theta_{1}$ & -0.348 & 0.085 & -4.07 \\
Rereg & $\theta_{2}$ & 0.026 & 0.058 & 0.45 \\
Inputs elasticities & & & & \\
w1 & & $0.243 * * *$ & 0.07 & 3.63 \\
w2 & & $0.372^{* *}$ & 0.13 & 2.86 \\
w3 & & $0.385^{* *}$ & 0.18 & 2.11 \\
Outputs elasticities & & & & \\
Q1 & & $0.639^{* * *}$ & 0.10 & 6.39 \\
Q2 & & $0.379^{* * *}$ & 0.09 & 4.21 \\
Q3 & & 0.007 & 0.02 & 0.35 \\
\hline
\end{tabular}


Table 6. TGR, CE and Meta-CE median values, 2001-2010.

Panel $A$ of this table reports the median values of the technological gap ratio (TGR); the country-specific cost efficiency (CE) and the meta-frontier cost efficiency (Meta-CE). The TGR measures the distance between the meta-frontier and the country frontier and it is $\leq 1$. The closer to 1 is a firm's TGR value, the closer that firm is to using the optimal meta-technology. Panel $B$ of the table reports the total number of technical leaders (i.e. banks with TGR $\geq 0.99$ ) in each country and their proportion in each ownership category. The countries in our sample are denoted as follows: CN (China); HK (Hong Kong); ID (Indonesia); IN (India);JP (Japan); MY (Malaysia); PH (Philippines); TH (Thailand).

\begin{tabular}{|c|c|c|c|c|c|c|c|c|c|}
\hline \multicolumn{10}{|c|}{ Panel A: Performance } \\
\hline & $\mathbf{C N}$ & HK & ID & IN & $\mathbf{J P}$ & MY & $\mathbf{P H}$ & TH & All \\
\hline TGR & 0.92 & 0.79 & 0.79 & 0.81 & 0.91 & 0.75 & 0.76 & 0.86 & 0.86 \\
\hline$C E$ & 0.96 & 0.92 & 0.96 & 0.98 & 0.98 & 0.94 & 0.96 & 0.98 & 0.97 \\
\hline Meta-CE & 0.86 & 0.71 & 0.75 & 0.78 & 0.89 & 0.71 & 0.73 & 0.84 & 0.82 \\
\hline \multicolumn{10}{|c|}{ Panel B: Technical leaders } \\
\hline & $\mathbf{C N}$ & HK & ID & IN & $\mathbf{J P}$ & MY & $\mathbf{P H}$ & TH & All \\
\hline Number & 45 & 7 & 1 & 1 & 19 & 2 & 0 & 2 & 77 \\
\hline \multicolumn{10}{|c|}{ Proportion: } \\
\hline State & 0.00 & 0.00 & 0.00 & 0.00 & 0.00 & 0.00 & 0.00 & 0.00 & 0.00 \\
\hline Private & 0.71 & 0.29 & 0.00 & 0.00 & 1.00 & 1.00 & 0.00 & 1.00 & 0.74 \\
\hline Foreign & 0.16 & 0.71 & 1.00 & 1.00 & 0.00 & 0.00 & 0.00 & 0.00 & 0.18 \\
\hline Coop & 0.13 & 0.00 & 0.00 & 0.00 & 0.00 & 0.00 & 0.00 & 0.00 & 0.08 \\
\hline
\end{tabular}




\section{Figure 1: Changes in ownership structure}

The graph plots the changes in ownership structure in the countries in our sample: $C N$ (China); HK (Hong Kong); ID (Indonesia); IN (India); JP (Japan); MY (Malaysia); PH (Philippines); TH (Thailand). Country-level data are from Bank Regulation and Supervision Survey (BRSS), Round I-IV, released by the World Bank in 2001, 2003, 2007 and 2012. The information reported corresponds to the period 1998-99, 2001, 2005, 2008-2010, respectively. HK data are compiled by the authors.

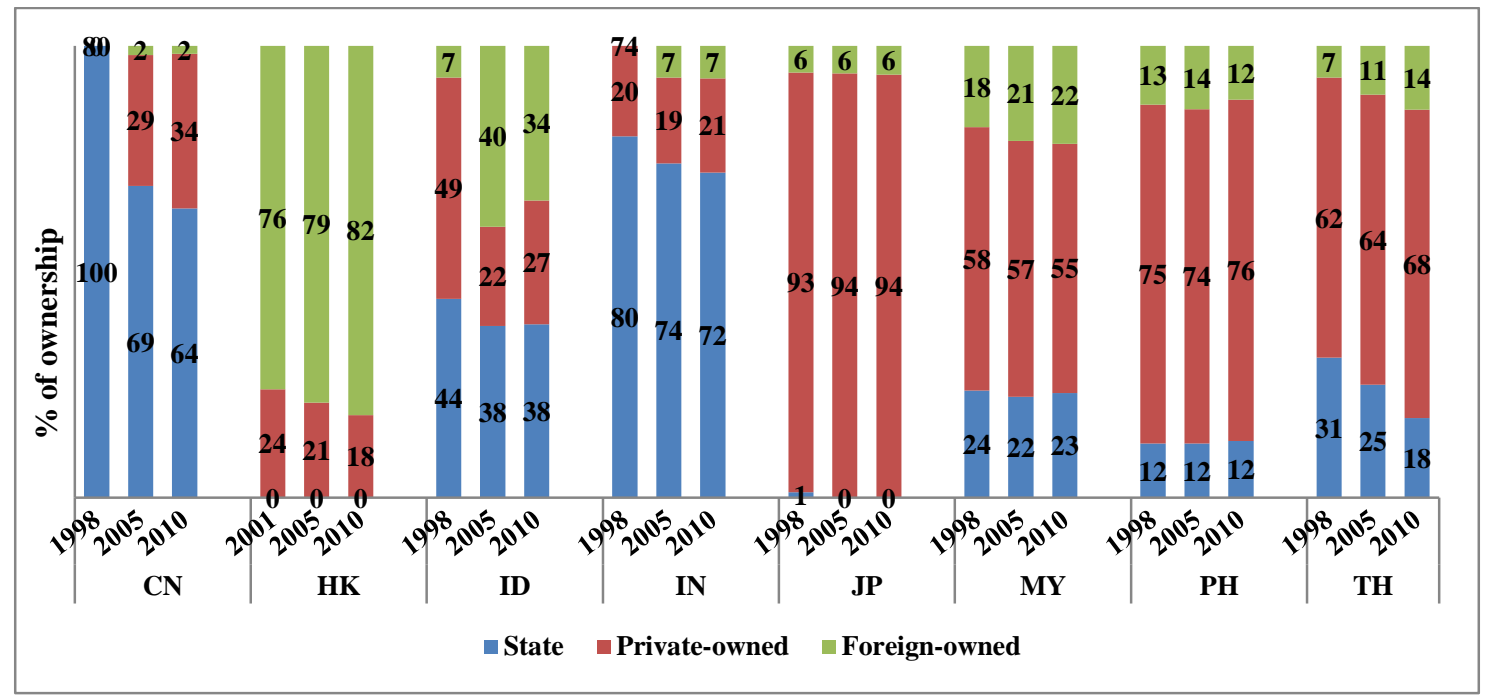

Page $\mid 49$ 
Figure 2: CR5 values, 1998-2010

This graph plots the share five-firm concentration ratio (CR5) calculated as the sum of the assets held by top 5 banks in each country. The countries in our sample are denoted as follows: CN (China); HK (Hong Kong); ID (Indonesia); IN (India); JP (Japan); MY (Malaysia); PH (Philippines); TH (Thailand). Country-level data are from Bank Regulation and Supervision Survey (BRSS), Round I-IV, released by the World Bank in 2001, 2003, 2007 and 2012. The information reported corresponds to the period 1998-99, 2001, 2005, 2008-2010, respectively. HK data are compiled by the authors.

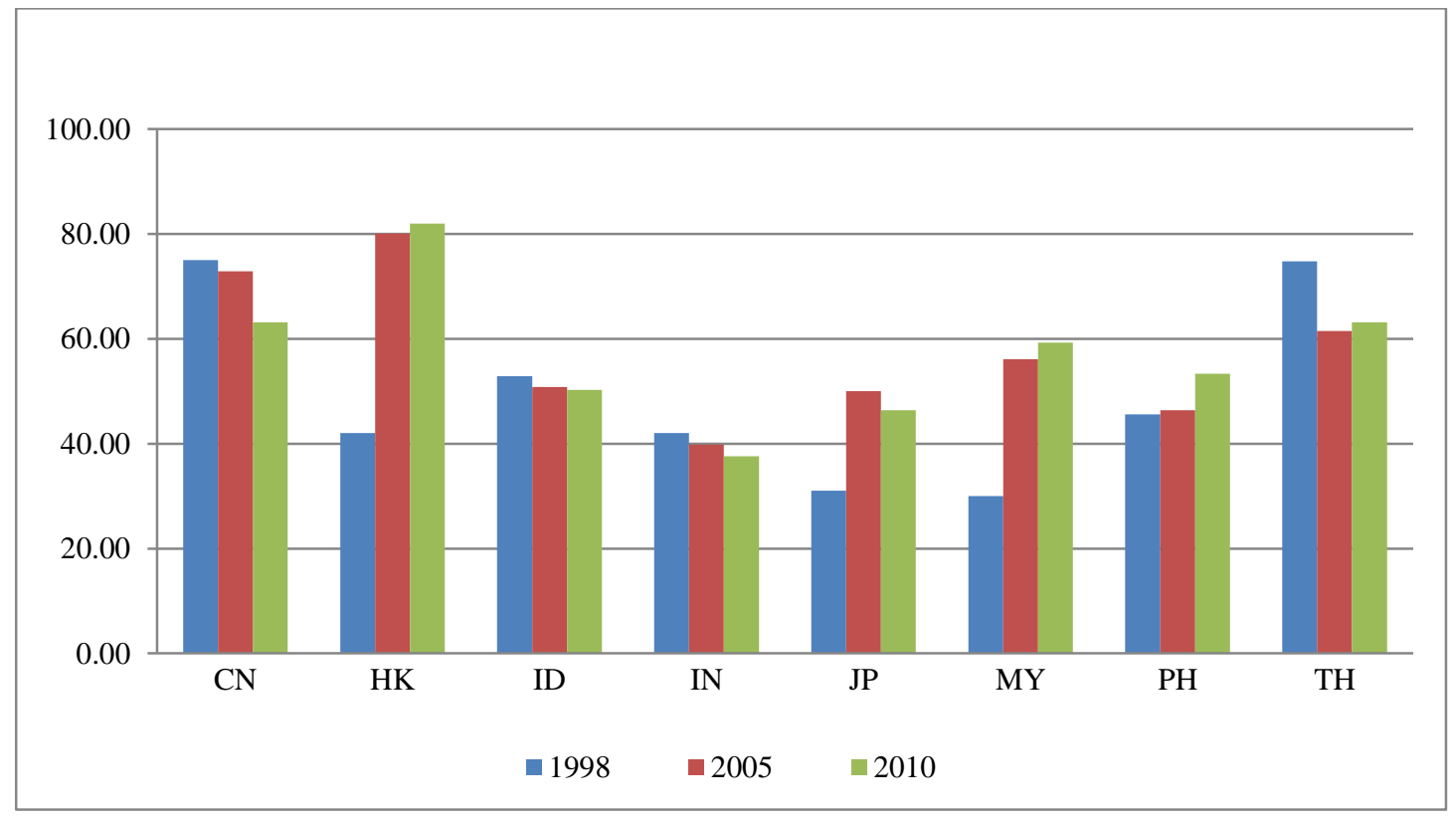


Figure 3. Changes in deregulation and re-regulation aggregate indices: 2001-2010

This graph plots the changes in the average deregulation and reregulation indices during the sample period. Dereg is the aggregate index of deregulatory measures, computed as the average of the individual indices. Rereg is the aggregate index of re-regulatory measures, computed as the average of the individual indices. For the definition and construction of the variables see Appendix A.

$\mathrm{CH}$

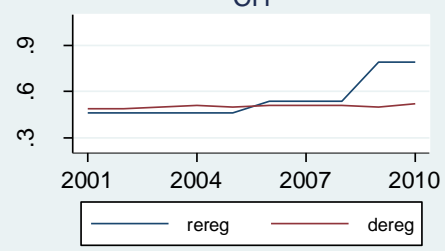

IN

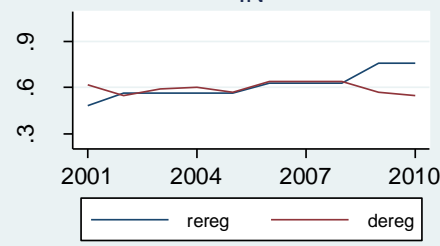

$\mathrm{PH}$

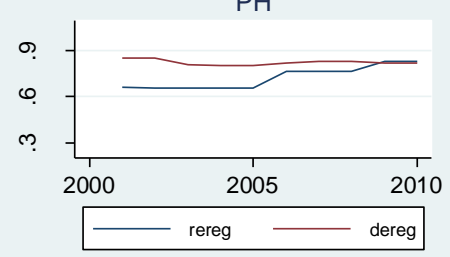

HK

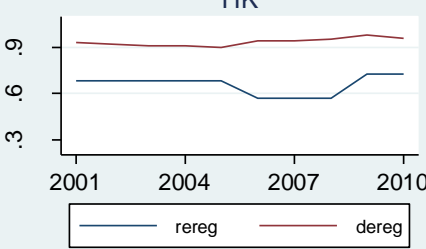

$\mathrm{JP}$

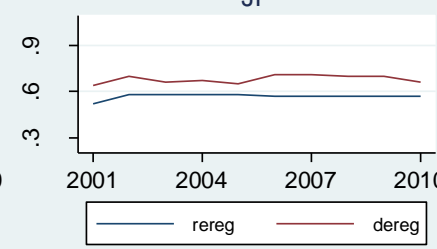

TH

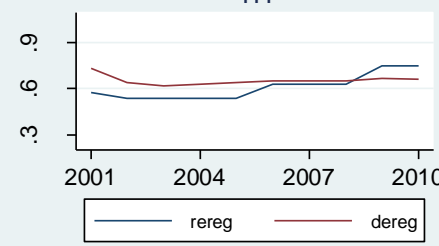

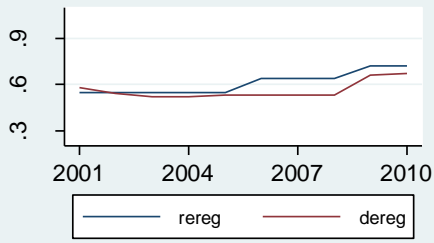

MY

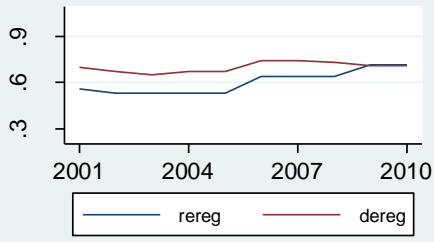




\section{Figure 4. Change of median performance measures over time}

This graph plots the evolution of cost efficiency and technological gap ratios (TGR) during the sample period. The countries in our sample are denoted as follows: CN (China); HK (Hong Kong); ID (Indonesia); IN (India);JP (Japan); MY (Malaysia); PH (Philippines); TH (Thailand).

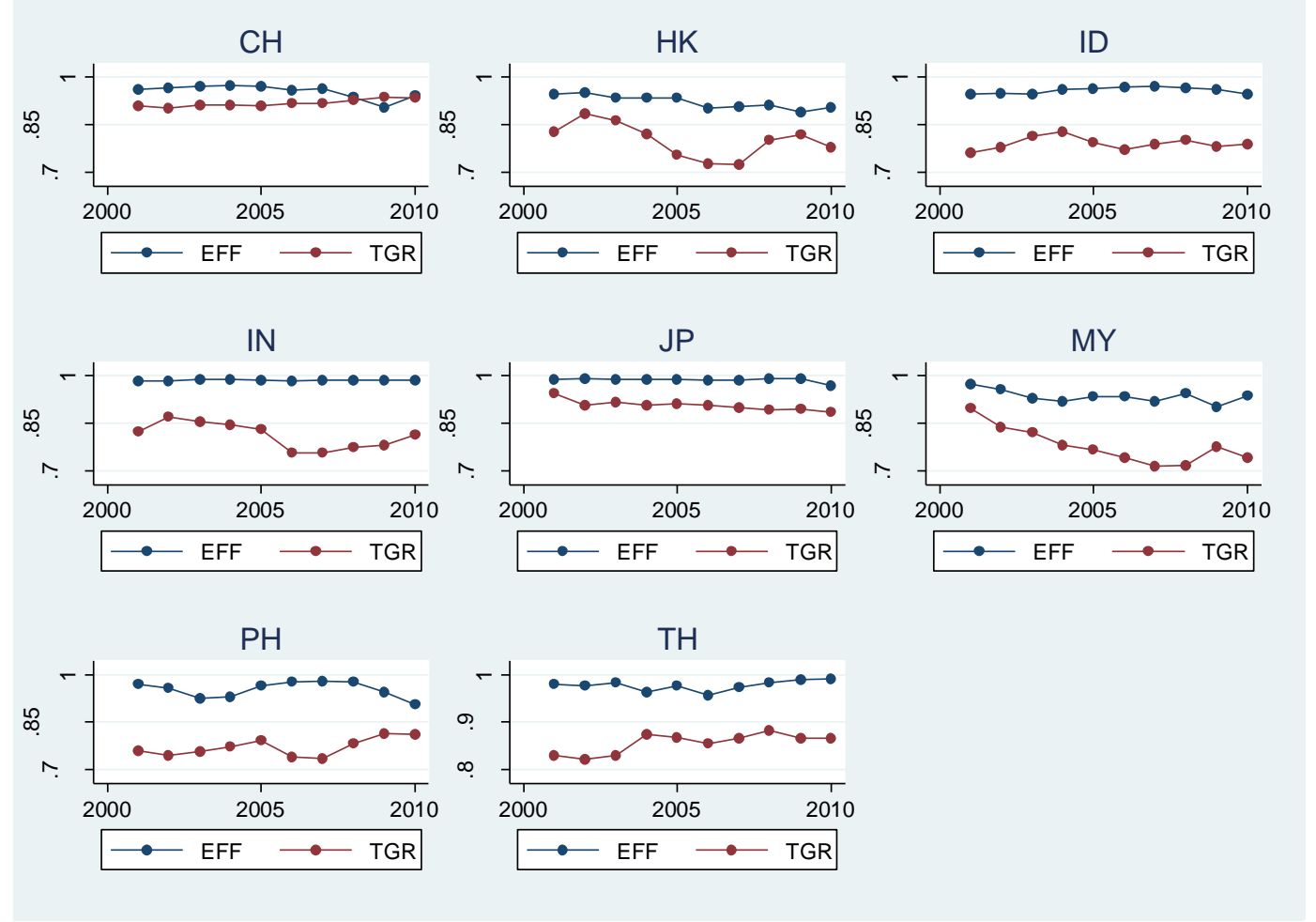

